\title{
The effect of matching on perceived export barriers and performance in an era of globalization discontents: Empirical evidence from UK SMEs
}

DOI:

10.1016/j.ibusrev.2018.03.007

\section{Document Version}

Accepted author manuscript

Link to publication record in Manchester Research Explorer

Citation for published version (APA):

Sinkovics, R. R., Kurt, Y., \& Sinkovics, N. (2018). The effect of matching on perceived export barriers and performance in an era of globalization discontents: Empirical evidence from UK SMEs. International Business Review, 27(5), 1065-1079. https://doi.org/10.1016/j.ibusrev.2018.03.007

\section{Published in:}

International Business Review

\section{Citing this paper}

Please note that where the full-text provided on Manchester Research Explorer is the Author Accepted Manuscript or Proof version this may differ from the final Published version. If citing, it is advised that you check and use the publisher's definitive version.

\section{General rights}

Copyright and moral rights for the publications made accessible in the Research Explorer are retained by the authors and/or other copyright owners and it is a condition of accessing publications that users recognise and abide by the legal requirements associated with these rights.

\section{Takedown policy}

If you believe that this document breaches copyright please refer to the University of Manchester's Takedown Procedures [http://man.ac.uk/04Y6Bo] or contact uml.scholarlycommunications@manchester.ac.uk providing relevant details, so we can investigate your claim.

\section{OPEN ACCESS}


The effect of matching on perceived export barriers and performance in an era of globalization discontents: Empirical evidence from UK SMEs

\section{This is a pre-print / an Author's Original Manuscript (AAM) of an article published by} Elsevier in International Business Review. Please cite the published article:

Sinkovics, Rudolf R., Yusuf Kurt, and Noemi Sinkovics (2018), "The effect of matching on perceived export barriers and performance in an era of globalization discontents: Empirical evidence from UK SMEs," International Business Review, 27(5), 1065-1079. https://doi.org/10.1016/j.ibusrev.2018.03.007

\section{$\underline{\text { Rudolf R. Sinkovics }}$}

The University of Manchester, Alliance Manchester Business School

Booth Street West, Manchester M15 6PB, UK.

Rudolf.Sinkovics@manchester.ac.uk http://www.manchester.ac.uk/research/rudolf.sinkovics

http://orcid.org/0000-0002-4471-5054

and

Lappeenranta University of Technology

Skinnarilankatu 34, PL 20, 53851 Lappeenranta, Finland and

Temple University, Fox School of Business, Department of Strategic Management Alter Hall, 1801 Liacouras Walk, Philadelphia, PA 19122, USA

\section{$\underline{\text { Yusuf Kurt }}$}

The University of Manchester, Alliance Manchester Business School

Booth Street West, Manchester M15 6PB, UK.

Yusuf.Kurt@manchester.ac.uk

http://www.research.manchester.ac.uk/portal/yusuf.kurt.html

http://orcid.org/0000-0002-5011-6322

\section{Noemi Sinkovics}

The University of Manchester, Alliance Manchester Business School

Booth Street West, Manchester M15 6PB, UK.

Noemi.Sinkovics@manchester.ac.uk

http://www.research.manchester.ac.uk/portal/Noemi.Sinkovics.html http://orcid.org/0000-0002-5143-6870

and

Temple University, Fox School of Business, Department of Strategic Management Alter Hall, 1801 Liacouras Walk, Philadelphia, PA 19122, USA 


\begin{abstract}
In this study we examine the effect of matching, a comprehensive networking concept, on the perceived export barriers and export performance of small exporting firms. We introduce matching as a moderating variable affecting the link of perceived internal/external export barriers to export performance. Using a sample of $106 \mathrm{UK}$-based exporting small and medium enterprises (SMEs), we find that matching alleviates the negative impact of perceived internal export barriers on export performance. Furthermore, the empirical results show that export experience and export commitment reduce managers' perceived internal and external export barriers. The study shows that matching, as a networking-tool at multiple levels, can help to overcome export barriers, thus providing a mechanism to offset challenges opened up through nationalistic policies.
\end{abstract}

\title{
Keywords
}

Internationalization; Matching; export barriers; export commitment; export performance; SMEs; anti-globalization.

\begin{abstract}
Author note
Correspondence should be addressed to Rudolf Sinkovics, The University of Manchester, Alliance Manchester Business School, Booth Street West, Manchester M15 6PB, United Kingdom. Email: Rudolf.Sinkovics@manchester.ac.uk, Web: www.manchester.ac.uk/research/rudolf.sinkovics
\end{abstract}

\section{Acknowledgements}

We gratefully acknowledge insightful comments received from Mo Yamin, S. Tamer Cavusgil and Ram Mudambi during seminars at The University of Manchester, Alliance Manchester Business School, UK and Fox School of Business, Temple University, Philadelphia, USA.

\section{Biographic notes}

Yusuf Kurt (PhD, The University of Manchester) is Lecturer (Assistant Professor) in International Business and Management at Alliance Manchester Business School, The University of Manchester. His current research interests include spirituality, social network analysis, internationalization, and emerging markets. His work has been published in International Marketing Review, European Management Journal and as chapter contributions. Email: Yusuf.Kurt@manchester.ac.uk 
Noemi Sinkovics (PhD, University of Manchester) is Lecturer (Assistant Professor) in International Business and Management at Alliance Manchester Business School, U.K and Visiting Scholar at Fox School of Business, Temple University. Her research focuses on International Entrepreneurship, ICT, and Economic Development issues. She has published in journals such as International Business Review, International Marketing Review, Journal of Business Research, Critical Perspectives on International Business, and European Journal of International Management. Email: Noemi.Sinkovics@manchester.ac.uk.

Rudolf R. Sinkovics (PhD, WU Vienna), is Professor of International Business at The University of Manchester, UK, Visiting Professor at Lappeenranta University of Technology, Finland and Visiting Scholar at Fox School of Business, Temple University. He has published on inter-organizational governance, the role of ICT in firm internationalization, and currently works on rising powers, and responsible business. Email: Rudolf.Sinkovics@manchester.ac.uk 


\title{
The effect of matching on perceived export barriers and performance in an era of globalization discontents: Empirical evidence from UK SMEs
}

\begin{abstract}
In this study we examine the effect of matching, a comprehensive networking concept, on the perceived export barriers and export performance of small exporting firms. We introduce matching as a moderating variable affecting the link of perceived internal/external export barriers to export performance. Using a sample of $106 \mathrm{UK}$-based exporting small and medium enterprises (SMEs), we find that matching alleviates the negative impact of perceived internal export barriers on export performance. Furthermore, the empirical results show that export experience and export commitment reduce managers' perceived internal and external export barriers. The study shows that matching, as a networking-tool at multiple levels, can help to overcome export barriers, thus providing a mechanism to offset challenges opened up through nationalistic policies.
\end{abstract}

Keywords: Matching; export barriers; export commitment; export performance; SMEs; antiglobalization.

\section{Introduction}

Faced with compound uncertainties in an era of rising nationalistic and protectionist policies and backlashes against globalization (e.g. Brexit in the UK and Trump's 'America first' approach to governance in the US), firms, particularly in their cross-border operations, are prompted to learn about and develop managerial strategies of navigating economic nationalism. Exporting firms have long enjoyed the incentives of the globalization era, accompanied by trade deals, international organizations, economic integration, and close relationships between countries, all of which have significantly facilitated the flow of goods, services, and capital across borders. The vibrant export activities across countries have significantly fostered welfare 
creation, socio-economic development, and job creation. However, the recent protectionist sentiments, encapsulated in 'anti-globalism' ' or 'globalization discontents' (Stiglitz, 2018), point at structural changes, and uncertainties in the international political-economic environment, that are likely to have serious effects on personal and organizational connectivity with partners (CanoKollmann, Hannigan, \& Mudambi, 2017). Institutional change, which was once a driver of globalization in the shape of pro-market reforms, has reversed, with governments imposing protectionist measures and weakening institutions such as the World Trade Organization (Cuervo-Cazurrra, Mudambi, \& Pedersen, 2017; Kobrin, 2017). Barrier-free relationships between countries and societies are likely to diminish (Helleiner \& Pickel, 2005) and in order to offset these, firms will have to move towards the development of relationships at multiple levels with different actors.

Network-based relationships are considered to be an effective way of navigating through uncertainties inherent in international operations, particularly during institutional transition periods (Meyer, 2001; Peng \& Zhou, 2005; Zhou, Wei-ping, \& Xueming, 2007). Hence, we examine the matching concept, introduced by Ghauri and Holstius (1996) to refer to a multitude of networking activities that firms conduct in order to interact with different actors at various levels, including customers, suppliers, local government, and trade unions, in developing crossborder relationships (Elg, 2008; Elg, Ghauri, \& Tarnovskaya, 2008; Ghauri \& Holstius, 1996). Compared with traditional networking relationships, which mainly focus on micro business relationships or on just one level of network relationships, matching extends to networks at the micro and macro levels. Our argument is that the simultaneous management of multiple levels of network relationships will support contemporary firms in overcoming internationalization barriers and foster export performance, specifically for small and medium-sized enterprises (SMEs) in an era of globalization discontents.

This paper develops a conceptual model in which matching is hypothesized as a moderating variable, i.e. shapes the relationship between perceived internal and external export barriers and export performance. Exporting experience, export commitment, and perceived export

1 Globalism refers to "the idea that, through a series of mechanisms, the world has become more closely interconnected, and by implication that it will continue to become more closely interconnected" (Dickson, 2013). It sees the world as characterized by networks of connections that span multi-continental distances (Keohane \& Nye, 2000; Nye, 2002). In contrast, globalization refers to the increase or decline in the degree of globalism and focuses on the forces and dynamism of these changes (Nye, 2002). 
barriers are introduced as independent variables and export performance as the dependent. While there is a plethora of prior work that examines direct impacts on export performance, the role of moderators is regarded to be underrepresented (Rose \& Shoham, 2002; Sousa, Martínez-López, \& Coelho, 2008). A study by Sousa et al. (2008, p. 366), providing a comprehensive review of the export performance literature, also suggests that "future studies should focus not solely on the main effects of independent variables on export performance, but also on whether the relationship between the independent and dependent variable varies as a function of the value of a third variable" and deliberately focus on moderating effects.

This paper contributes to the literature as follows. Firstly, it examines the moderating effect of matching on the relationships between perceived export barriers and export performance. Whereas most of the previous work is limited to micro-level business networks and their direct impact on firms' exporting behaviors, we introduce matching to delineate to what extent the moderating impact of networking activities at micro and macro levels can alleviate perceived export barriers and thus foster export performance. Secondly, this paper systematically integrates perceived internal and external export barriers and investigates their impact on export performance, whereas previous empirical evidence on that integration has been limited. This provides a more nuanced understanding of the nature and type of barriers that SMEs encounter.

\section{Theoretical background and conceptual framework}

\section{$2.1 \quad$ Exporting and network-based SME internationalization}

Exporting is seen as a baseline cross-border activity, particularly useful for SMEs, as their organizational structure, size and management system puts pressure on their ability to devote resources towards internationalization and connecting with international markets (Chetty \& Blankenburg Holm, 2000; Navarro, Acedo, Robson, Ruzo, \& Losada, 2010a; Uner, Kocak, Cavusgil, \& Cavusgil, 2013). It offers a fast, cost-effective, and risk-reducing approach to internationalization, combined with high flexibility (Golovko \& Valentini, 2011; Lu \& Beamish, 2006). The benefits associated with exports are not restricted to firms, as countries also gain significantly from them (Pinho \& Martins, 2010). Exporting plays a vital role in promoting socioeconomic development, and contributes to countries' GDP, economic growth, employment, and welfare creation (Pinho \& Martins, 2010). For instance, it is an important contributor to GDP in the UK, the EU, and OECD countries. Exports of goods and services as ratios of GDP are 28.1\% 
for the UK, $43 \%$ for the EU and $28.4 \%$ for OECD countries (OECD, 2016). Exporting is also an important driver of job creation. As indicated in the 2016 European Commission report, one in seven jobs in the EU was either directly or indirectly supported by exports to the rest of the world (Rueda-Cantuche \& Sousa, 2016). The number of jobs supported by extra-EU exports increased by around three million between 2000 and 2007 (Sousa, Rueda-Cantouche, Arto, \& Andreoni, 2012). These significant contributions and attractive benefits of exporting activities, for firms, countries, and societies, could be eroded by the onset of an anti-globalization era that is likely to turn interconnected markets into isolated islands. Hence, deepening our understanding of export barriers and networking strategies for overcoming them is becoming particularly crucial.

Within the international business (IB) and international entrepreneurship (IE) literatures, the network model of firm internationalization has received strong interest (Coviello, 2006; Ghauri, Lutz, \& Tesfom, 2003; Kurt \& Yamin, 2016; Loane \& Bell, 2006; Musteen, Francis, \& Datta, 2010; Zhou et al., 2007). Whereas traditional internationalization theories mostly employ a firm-centric focus (i.e., Johanson \& Vahlne, 1977), its later theorizations have extensively applied relational approaches and understand internationalization as a dynamic process through which firms are engaged in a diverse range of network relationships (Ellis, 2000; Johanson \& Vahlne, 2003, 2009; Yamin \& Kurt, 2018). A well-established body of the literature on SMEs and rapidly internationalizing entrepreneurial firms (i.e. born-globals or international new ventures) has empirically demonstrated the relation between network propensity and firms' internationalization performance by focusing on firms' business, social, and also macro-level political/institutional networks (Cavusgil \& Knight, 2015; Coviello, 2006; Kiss \& Danis, 2010; Li \& Zhang, 2007; Manolova, Manev, \& Gyoshev, 2010; Sharma \& Blomstermo, 2003; Zhang, Ma, Wang, Li, \& Huo, 2016; Zhou et al., 2007). The rise and success of rapidly internationalizing entrepreneurial SMEs has been thought to be facilitated by the contemporary global business environment and widening multi-country networks comprising different actors (Cavusgil \& Knight, 2015).

Moreover, a stream of research in the IB and IE literatures has focused on macro-level networks as an important component of non-market strategy in IB activities. This body of research has mainly focused on the value of political embeddedness, with reference to political actors and institutions, for organizational performance (Frynas, Mellahi, \& Pigman, 2006; Sun, Mellahi, \& Thun, 2010; Sun, Mellahi, \& Wright, 2012). From a non-market strategy perspective, 
network ties are seen as boundary-spanning personal and institutional linkages between firm and government agents, which play a crucial role in determining performance outcomes and IB success (Doh, Lawton, \& Rajwani, 2012; Sun et al., 2012). Being embedded in macro-level political networks of home and host countries is considered an effective means of capturing nonmarket and political resources that create and sustain competitive advantages in cross-border business activities (Hillman, Keim, \& Schuler, 2004; Peng \& Luo, 2000). Despite their separate and narrow focus on either the micro or the macro level of network relationships, one key overarching argument of these research streams has been that networks are one fundamental determinant of firms' success or failure in IB activities, particularly in the contexts of small and entrepreneurial firms.

However, existing research on the networks of small and entrepreneurial firms has been unable to grasp a holistic picture of the network dynamics, as it has mostly adopted a micro perspective, with an extensive focus on inter-firm and business-level relationships. Scholars have also highlighted that this body of research has underemphasized the importance of network relationships with socio-political and non-business actors in non-market environments (Elg et al., 2008; Hadjikhani \& Ghauri, 2001; Hadjikhani, Lee, \& Ghauri, 2008). Furthermore, previous studies have investigated different types of networking activities (social, business, and macrolevel networks) separately and neglected firms' simultaneous composition of different levels of network relationships with multiple actors. Yet, entering a foreign market requires the consideration of a broad range of external stakeholders, beyond firm-level relationships (Mark \& Quinn, 2005). Firms need to interact with different actors to gain the knowledge necessary to respond to required market adaptations, and also to gain support and approval in the host country (Elg et al., 2008). Accordingly, the network approaches in this body of research need to be elevated to a broader and more comprehensive level that deals with different levels of networking activities with actors in both market and non-market environments, in order to develop a more holistic and nuanced understanding of the potential role of networks in firm internationalization.

Building on the export marketing and network-based internationalization literature, we propose a conceptual model in which export barriers, export commitment, and exporting experience relate directly with export performance. Specifically, we argue that the exporting experience and commitment of entrepreneurs exhibit positive effects on export performance. This is in line with a vast body of previous literature (Bloemer, Pluymaekers, \& Odekerken, 2013; 
Cavusgil \& Zou, 1994; Dean, Mengüç, \& Myers, 2000; Navarro, Losada, Ruzo, \& Díez, 2010b; Zou \& Stan, 1998). The model also hypothesizes that export commitment and exporting experience reduce managers' perceived barriers to exporting. More importantly, we extend the rather solid understanding of the link between perceived export barriers and export performance by introducing firms' micro and macro levels of matching activities, which are suggested to moderate the relationship between perceived internal/external export barriers and export performance. The following sections provide the development of the hypothesized relationships.

\subsection{Export performance}

Export performance, which has been one of the central constructs in the export marketing literature, is defined as the extent to which a firm can accomplish strategic and economic objectives with respect to exporting to a foreign market (Cavusgil \& Zou, 1994; Shoham, 1998). It has been considered a key indicator for managers to use to make decisions regarding international operations, since it fosters growth and ensures company survival in the long term (Madsen, 1998; Navarro et al., 2010b; Sousa et al., 2008). Previous research has focused extensively on the determinants of export performance, such as management's perceptions and willingness to take risks, managerial characteristics, and firm competencies, to name a few (see Aaby \& Slater, 1989 for a comprehensive and integrative review; Cavusgil, 1984; Morgan, Kaleka, \& Katsikeas, 2004; Navarro et al., 2010b; Zou \& Stan, 1998 ). However, fewer studies have connected export barriers to export performance, and the factors that might alleviate those barriers. Additionally, existing research has mostly investigated the direct impact of independent factors on export performance and as highlighted by Sousa et al. (2008), only a few researchers have considered the existence of moderating effects to explain the export performance of the firm. This current research thus attempts to bridge the gap in the literature by considering both factors directly affecting export performance, and also introducing matching as a moderating variable which acts on the relationships between the independent variables and export performance, as follows.

\subsection{Export barriers faced by small and entrepreneurial firms}

SMEs and entrepreneurial firms gain from exporting due to scale and scope economies, increases in market power, the generation of revenues from diversified activities, the spread of 
business risks across different markets, product quality improvements, the use of idle capacity, and production efficiency improvements, as well as from becoming more attractive to shareholders and employees (Leonidou, 2004a). However, realizing these benefits has frequently proved troublesome, due to a number of barriers that impede the exporting process, inhibit financial gains, provoke negative attitudes towards exporting, or even threaten firm survival (Leonidou, 1995).

Export barriers can be defined as the structural, attitudinal, operational, and environmental factors that hinder or discourage firms, particularly SMEs, from initiating, increasing, or maintaining export activities (Arteaga-Ortiz \& Fernández-Ortiz, 2010; Kahiya, Dean, \& Heyl, 2014; Leonidou, 1995). Previous research established a negative link between perceived export barriers and export performance (Silva \& Rocha, 2001; Wilkinson \& Brouthers, 2006). The underpinning relationship between managers' perceived export barriers and export performance can be understood through the barriers' impacts on strategic decisions regarding export activities. Previous studies confirmed that with managers' perception of barriers increasing, attitudes towards exporting decrease (Donthu \& Kim, 1993; Moini, 1997; Pinho \& Martins, 2010). Wilkinson and Brouthers (2006, p. 235) underlining that "the attitudes exhibited by managers toward exporting play a significant role in whether or not firms become involved in exporting and, if they do, their subsequent progress". Hence, export barriers affect firms' strategic decisions, which in turn affect export development and performance (Suarez-Ortega, 2003). Silverman, Sengupta, and Castaldi (2004) also found a negative relationship between export barriers and export performance, in their research examining the US wine industry (see also Javalgi, Griffith, \& White, 2003; McNaughton, 2003).

Export barriers are mainly classified as internal or external barriers (Cavusgil \& Zou, 1994; Leonidou, 2004a; Tesfom \& Lutz, 2006). Cavusgil and Zou (1994) argue that exporting should be seen as a firm's strategic response to internal and external forces. The literature shows that both internal and external barriers have a significant impact on firms' exporting performance (Cavusgil \& Zou, 1994; Katsikeas \& Morgan, 1994; Leonidou, 2004a).

Internal barriers are intrinsic to the firm and mostly associated with the firm's insufficient organizational resources and capabilities such as market information, international experience, capital, and competent personal, to name a few, required for export activities (Tesfom \& Lutz, 
2006). They are mostly related to the 'intrinsic' characteristics of the SMEs and entrepreneurial firms; as a consequence of the very nature of their smaller size (Zhou et al., 2007). Leonidou (2004) classified internal barriers as functional, information and marketing barriers. Internal barriers, such as limited market information, lack of experience and a lack of managerial support, could hinder a firm's exporting capabilities regarding identification and exploitation of opportunities in a particular foreign market and hence export performance. Lack of organizational capability (i.e. marketing knowledge, financial and human resources) in executing marketing strategy in foreign markets has also been identified as one of the key internal barriers hindering export performance (Katsikeas \& Morgan, 1994). In addition, barriers such as a lack of proper control over foreign distributors can pose a threat of the distributors exhibiting opportunistic behaviors, and thus hampering the firm's exporting performance. Accordingly, we put our hypothesis as follows;

H1a: The higher the perceived internal export barriers, the lower is the firms' export performance.

External barriers stem from the environment in which firms operate, and can emanate either from the domestic market or the host markets (Morgan, 1997; Tesfom \& Lutz, 2006). Leonidou (2004) classified external barriers as procedural, governmental, task, and environmental. These barriers usually fall beyond the control of individual firm and are affected by rapid external changes (ibid). Previous studies identified external barriers as one of the key antecedents of export performance (Aaby \& Slater, 1989; Calantone, Kim, Schmidt, \& Cavusgil, 2006; Cavusgil \& Zou, 1994; Sousa et al., 2008). A firm perceiving significant external barriers is likely to have negative attitudes towards exporting which will also be reflected in their export performance (Dean et al., 2000). In this vein, external barriers such as economic, political, and cultural risks can curb a firm's exporting marketing activities and hinder performance outcomes. For instance, exporting to developing countries, which are generally characterized as more volatile environments involving unstable political contexts, might discourage firms from engaging in export activities and thus negatively affect export performance. External barriers can particularly hinder small exporters' performance, as they lack resources and capabilities to offset uncertainties emerging from external environment (Shoham \& Albaum, 1995; Tesfom \& Lutz, 2006). We follow the extensive previous literature arguing that the external barriers perceived by managers negatively affect export performance, and specify our hypotheses as follows: 
H1b: The higher the perceived external export barriers, the lower is the firms' export performance.

\subsection{Export commitment}

Export commitment has been defined as managers' willingness to devote adequate financial, managerial, and human resources to export-related activities (Donthu \& Kim, 1993; Navarro et al., 2010b). Whereas this definition refers to a more attitudinal perspective, Cavusgil and Zou (1994) applied a behavioral approach, which is also used in this study, and defined it as the resources a firm currently devotes to exporting activities. Existing research has investigated the antecedents and outcomes of export commitment (e.g. Navarro et al., 2010a), and also its relationship with export performance (Navarro et al., 2010a; Zou \& Stan, 1998), which is generally acknowledged to be positive (Cavusgil \& Zou, 1994; Dhanaraj \& Beamish, 2003; Navarro et al., 2010b). However, the prior focus has mainly been on the direct impact of export commitment on export performance, and its indirect impact via other independent determinants of export performance has not been sufficiently investigated. For instance, managers' commitment towards exporting activities can change the way and extent to which they perceive barriers, with more committed and risk-taking managers tending to perceive them less intensely than less committed, inward-oriented, and risk-averse managers (Leonidou, 2004a). Export commitment can thus affect export performance both directly and indirectly through managers' perceptions of export barriers. It is therefore important to reveal the interactions among the independent factors, in order to develop a more comprehensive and nuanced understanding of the determinants of export performance.

Our approach to export commitment is consistent with a number of previous studies dealing specifically with the influence of managerial characteristics on firms' internationalization. Export commitment reflects a managerial characteristic relating to the behavioral disposition of the decision makers with respect to risk taking and the undertaking of expansion activities (Nummela, Saarenketo, \& Puumalainen, 2004; Suarez-Ortega \& AlamoVera, 2005). Commitment to export is seen as a critical determinant of export performance (Cavusgil \& Nevin, 1981; Cavusgil \& Zou, 1994; Navarro et al., 2010b; Wiedersheim-Paul, Olson, \& Welch, 1978). Committed managers carefully plan strategic decisions and allocate sufficient resources to exporting activities (Cavusgil \& Zou, 1994). 
Export commitment is also capable of alleviating managers' perceived export barriers and are thus critical to the success of SMEs' and entrepreneurs' exporting endeavors. It can increase managers' willingness to achieve international objectives and provide a strategic guideline for their decision making in foreign markets, which in turn improves the efficiency and effectiveness of resource allocation, stimulating international sales (Lages \& Montgomery, 2004; Navarro et al., 2010b). The way that managers perceive the internal and external environment can be an outcome of their strategic orientation when it comes to exporting activities. Leonidou (2004b, p.284) indicated that "firms whose decision-makers are rather incompetent, risk-averse, and inward-looking are very likely to perceive export obstacles in a more intense and severe manner than firms with capable, risk-taking, and foreign-oriented managers". It is likely that highly committed managers are more risk taking and foreign-oriented, and hence tend to perceive export barriers less intensively. This argument is consistent with a number of previous studies dealing with the role managerial characteristics play in determining the perceptions of export barriers (Carrier, 1999; Forlani, Parthasarathy, \& Keaveney, 2008; Ruzzier, Antoncic, Hisrich, \& Konecnik, 2007). Whilst firms are exposed to a number of factors that stimulate and/or obstruct export activities, the effects of such factors will depend on the way they are perceived by the decision maker (Forlani et al., 2008; Wiedersheim-Paul et al., 1978). We argue that the more committed the management team is to exporting, the less intensely they will perceive the export barriers to be.

In general, the literature supports the idea that export commitment positively affects export performance and also that the characteristics of the firm's decision makers, including their commitment to exporting, can significantly influence the way the barriers are perceived (Leonidou, 1995; Navarro et al., 2010b). On this basis we hypothesize:

H2: The higher the managers' export commitment, the higher is the firm's export performance.

H3a: The higher the managers' export commitment, the lower they perceive the internal export barriers to be.

H3b: The higher the managers' export commitment, the lower they perceive the external export barriers to be. 


\subsection{Export experience}

The literature also suggests export experience as one of the key determinants of export performance (Love, Roper, \& Zhou, 2016; Sousa et al., 2008). The extant literature on SMEs has identified a plethora of barriers leading to uncertainties and potentially inhibiting exporting (Altıntaş, Tokol, \& Harcar, 2007; Silva \& Rocha, 2001; Tesfom \& Lutz, 2006). On the other hand, export experience has been considered a key factor in reducing these uncertainties related to exporting. Katsikeas, Piercy, and Ioannidis (1996, p.14) indicated that "with increasing exporting experience, firms are likely to perceive less uncertainty in their exporting activities". The theoretical explanation for the relationship between export experience and performance lies mainly in the notions of uncertainty and learning (Forsgren, 2002; Katsikeas et al., 1996). The decision to export is characterized by a considerable amount of uncertainty stemming from a lack of foreign market knowledge, which can be acquired through experience gained from a firm's cross-border activities (Forsgren, 2002; Katsikeas \& Morgan, 1994; Sousa et al., 2008). More experienced exporters are likely to perceive less uncertainty and fewer barriers in their exporting activities, and demonstrate a higher propensity to export (Forsgren, 2002; Leonidou \& Katsikeas, 1996). Learning through export experience can also help firms to develop capabilities, enabling them to better understand foreign markets and design effective exporting strategies leading to higher export performance outcomes (Forsgren, 2002; Johanson \& Vahlne, 2009; Katsikeas et al., 1996).

Existing research indicates that export experience significantly affects firms' capacity and ability to make adequate use of information when facing threats and opportunities in foreign markets (Cavusgil \& Zou, 1994; Julien \& Ramangalahy, 2003). Previous studies have found a positive relationship between export experience and export performance (Dean et al., 2000; Navarro et al., 2010a; Shaoming Zou \& Cavusgil, 2002; Zou \& Stan, 1998). Moreover, it has been empirically proven that export experience reduces uncertainty and the export barriers perceived by managers (Katsikeas \& Morgan, 1994; Leonidou, 2000; Shoham \& Albaum, 1995).

For instance, Leonidou (2000) found that the less export experience a firm has, the more acutely export barriers are perceived. Accordingly, we also suggest that a higher level of export experience leads to lower perceived export barriers and higher export performance: 
H4: The greater the managers' export experience, the higher is the firm's export performance.

H5a: The greater the managers' export experience, the lower they perceive the internal export barriers to be.

H5b: The greater the managers' export experience, the lower they perceive the external export barriers to be.

\subsection{The moderating role of matching}

Matching is the central construct of this research, as a moderator of the relationships between perceived export barriers and export performance. It is defined as consisting of all the measures taken at the global, macro, and micro levels to facilitate the development of crossborder business relationships (Ghauri \& Holstius, 1996). Matching activities are considered an essential ingredient of a successful market entry, since firms need to interact with a number of different actors on different levels of activity to gain approval, understand adaptations, and gain acceptance (Elg et al., 2008). Matching involves firms' own relationships with different actors such as governments, unions, and suppliers. Matching between governments at a macro level can also provide support and approval for firms' cross-border activities (Elg et al., 2008). Whereas the traditional network approach deals with relationships between business actors, matching, as a more comprehensive concept, helps us to understand how a firm's business position can be strengthened by support from both business and non-business actors (Elg et al., 2008; Ghauri \& Holstius, 1996). In our particular context, matching is seen as a multi-level networking tool, which is helpful in alleviating some of the contemporary pressures that arise due to globalization discontents.

Matching includes three levels of activities. Global networks primarily refer to international institutions such as the World Bank, the IMF and the WTO. In this study, the focus is on the macro and micro levels of matching. The macro level of matching refers to the level of support provided by host and home governments for business activities, through measures taken bilaterally by governments and other social actors to facilitate entry (Elg et al., 2008; Ghauri \& Holstius, 1996; Leelapanyalert \& Ghauri, 2006). The macro level of matching extends the interactions between business actors to non-business actors such as governments and other social actors involved in export markets. It has been demonstrated that small and entrepreneurial firms can conduct their international marketing activities more successfully, and thus enhance their 
export performance, through host and local government support and by building relationships with local actors (Babakus, Yavas, \& Haahti, 2006; Ghauri et al., 2003; Johanson \& Vahlne, 1990). Recent studies also provide empirical evidence suggesting that international entrepreneurs' institutional capital, which refers to support and linkages with home-country government programs, can be a valuable resource driving firms' international performance (Lu, Zhou, Bruton, \& Li, 2010). Matching at global and macro levels creates preconditions for company-level cooperation and micro-level matching activities (Ghauri \& Holstius, 1996). The micro level of matching is closely related to networking with competitors, customers, and other actors, for the realization of a successful market entry (Ghauri \& Holstius, 1996; Leelapanyalert \& Ghauri, 2006). This level of matching is similar to the business network approach (Leelapanyalert \& Ghauri, 2006), which in the context of increasing globalization discontents and uncertainties about future trading relationships, is pertinent as a strategic risk reduction networking tool.

The key assumption of the network approach is that firms require resources controlled by other firms, which can be acquired through network relationships (Chetty \& Blankenburg Holm, 2000; Zhou et al., 2007). Piercy, Kaleka, and Katsikeas (1998) asserted that underpinning superior export performance is a firm's ability to manage a complex network of relationships. The benefits that accrue to a firm from its networking activities are widely cited in the literature. Networks can provide a firm with access to resources and opportunities (Chetty \& Blankenburg Holm, 2000), increase synergistic effects (Elg \& Johansson, 1996), enhance competitive advantage (Welch, Welch, Young, \& Wilkinson, 1998), and overcome constraints, especially those stemming from a comparatively small firm size (Donckels \& Lambrecht, 1997; Loane \& Bell, 2006; Zhou et al., 2007). Additionally, Ghauri et al. (2003) argued that networks are often used to alleviate internal and/or external export barriers. Accessing external resources through network relationships can help SMEs to overcome internationalization and export barriers, particularly those stemming from a lack of resources and experience and the liability of smallness (Chetty \& Wilson, 2003; Demick \& O'Reilly, 2000; Welch et al., 1998). More specifically, it has been suggested that networks (with customers, suppliers, other companies, and authorities in both the domestic and foreign market) enable firms, particularly small and entrepreneurial firms, to minimize or even overcome their size disadvantages, as these networks enable them to exchange valuable information, leverage the skills and resources of others, access opportunities, and 
generally benefit from the positive synergistic effects of such networks (Chetty \& Wilson, 2003; Holm, Eriksson, \& Johanson, 1999; Loane \& Bell, 2006; Ojala, 2009). However, little of the earlier work on the business network approach paid attention to the political relationships of firms, or to the influence of actors (i.e. political and social actors) from the non-market environment on firms' cross-border activities (Hadjikhani \& Ghauri, 2001). Matching activities can enable firms to exploit a broader range of market and non-market resources through relationships with multiple businesses and political and social actors. These different levels of business activities, with actors from both market and non-market environments, can help exporting SMEs to overcome perceived internal/external export barriers by acquiring information, resources, support, and approval from multiple stakeholders and mitigate against unfavorable macro-level political trading relationships.

The above evidence supports the notion that matching reduces perceived internal and external barriers, which can in turn weaken their negative effects on export performance. Fundamentally, these moderating effects occur because the 'quality' of export-related decision making is likely to improve, partly as a result of better and more reliable information generated through matching and networking, and partly because the impact of constraints on decision making (such as risks stemming from opportunistic behavior engaged in by counterparts) are alleviated (Ghauri et al., 2003). More specifically, matching could help management to overcome the barriers associated with the disadvantages of their firms' size and their isolation from foreign markets, specifically in an environment that exhibits increasingly negative views about globalization and trade-relationships with foreign partners (Barnett, 2017). Informational barriers could be reduced with increased knowledge of the foreign market gained through a firm's linkages with already-established suppliers, while problems of product reconfigurations and adaptation of marketing procedures, as well as socio-cultural differences, could be resolved through firms' connections with business and non-business actors in the foreign market. The macro-level matching could help the management to reduce the impact of governmental and environmental barriers on export performance (Ghauri et al., 2003) as well as uncertain trading relationships (Welfens, 2017). We therefore argue that networking with customers, competitors, governments, and other relevant stakeholders could reduce the unfamiliarity and uncertainty an exporter faces when attempting to access a foreign market, and enable it to adapt promptly and effectively to the new situation. Moreover, through local or host government support, the 
management of SMEs and entrepreneurial exporters could minimize their uncertainty regarding the different rules and regulations that might have to be overcome, while at the same time increasing their awareness and chance of utilizing any available government assistance, for their own benefit (Ghauri et al., 2003). Accordingly, we put our hypotheses as follows:

H6: $\quad$ The higher the level of matching, the higher is the firm's export performance.

H7a: The higher the level of matching, the weaker is the negative influence of internal export barriers on export performance.

H7b: The higher the level of matching, the weaker is the negative influence of external export barriers on export performance.

Figure 1 illustrates all the hypothesized relationships among export commitment, export experience, export barriers, export performance, and matching.

\section{Insert Figure 1 around here}

\section{Methodology}

\subsection{Sample}

A list of firms was generated from the population of firms covered in the Department of Trade and Industry (DTI) UK database. Firms included in the list had to meet the two criteria of being SMEs, according to the EU definition based on firm size (fewer than 250 employees), and of being based in the North West of England. Some specific government initiatives had been taken by the North West Development Agency (NWDA) in this specific area, and we aimed to explore the managerial relevance and impact of these initiatives. The criteria yielded 900 firms across all manufacturing industries. We mainly focused on the manufacturing business and did not include intermediate trade organizations, trading agents, or service firms, as it would have been difficult to accurately specify the value of the goods traded. A questionnaire was sent to each firm with the support and endorsement of the NWDA. The respondents were those deemed most knowledgeable about the firms' exporting business, such as marketing managers and senior managers. Support and engagement from the NWDA was vital as we drew on elements of Dillon's 'Tailored Design Method' (Dillman, Smyth, \& Leah, 2014) and aimed to meet 
requirements regarding 'social exchange' (Dillman et al., 2014; Emerson, 1962) to improve industry cooperation and response rates. Multiple contacts by phone and email were employed, replacement questionnaires were sent out, and industry reports were offered.

\subsection{Data collection and assessment of common method bias}

A total of 900 questionnaires were distributed to the firms identified in the North West of England. Having employed the aforementioned social exchange procedures and multiple contacts, 106 usable responses were obtained, a response rate of about $11.7 \%$. This reflects a good representation of the population, considering the difficulties encountered in survey projects these days, and also the decline in response rates reported in organizational and IB research journals (Chidlow, Ghauri, Yeniyurt, \& Cavusgil, 2015; Rogelberg \& Stanton, 2007). Following the recommendation of Baruch and Holtom (2008), we assessed non-response bias by classifying the responses into two groups, early responses and late responses (Armstrong \& Overton, 1977; Rogelberg \& Stanton, 2007). Furthermore, independent t-tests on demographic variables such as revenue and employee numbers were performed. No significant differences emerged. We ran additional t-tests between these two groups, on key variables in the proposed conceptual model, such as export barriers. Again, no significant difference emerged, hence non-response bias was deemed not to present a problem in our dataset (Armstrong \& Overton, 1977; Rogelberg \& Stanton, 2007).

As our data were collected based on self-reports, there existed the potential for the occurrence of common method bias. Following the recommendation of Podsakoff and Organ (1986), we conducted a Harman one-factor test and found that no dominant factor emerged (the first factor explains only $13 \%$ of the total variance). This result confirmed that common method bias would not be a major threat to our subsequent hypothesis testing.

\subsection{Measurement}

The questionnaire was developed with reflective measurement scales, and the items for each construct were taken from established and validated scales. The first part of the questionnaire focused on managers' perceptions of barriers. The second part concentrated on the export commitment, matching, and export performance evaluations of the respondents. The operationalization of each construct was as follows: 
Export barriers: For the first part of the questionnaire, the entrepreneurial firms' managers were asked to rate to what extent they felt each barrier, as identified by Leonidou (2004a), posed a challenge to their firm's exporting activities. Response levels were anchored on a seven-point Likert scale ranging from "very much" (7) to "not at all" (1). A total of 16 internal/external export barriers were listed. The internal barriers construct included "functional" barriers (such as lack of managerial time to deal with exports, inadequate/untrained personnel for exporting, shortage of working capital to finance exports), "informational barriers" (such as lack of information about international markets and foreign business opportunities etc.), and "product", "logistics", and "distribution" barriers (such as unavailability of warehousing facilities abroad, difficulty of supplying inventory abroad, and difficulty of developing new products for foreign markets). The external barriers construct included "socio-cultural" barriers (different socio-cultural traits etc.), "procedural" barriers (unfamiliar exporting procedures/documentation and unfavorable home rules and regulations), "task" barriers (such as unfamiliar foreign business practices), and "economic" and "political-legal" barriers (such as foreign currency exchange risks, strict foreign rules and regulations, slow collection of payments from abroad, and hightariff and non-tariff barriers).

Export commitment: We assessed the level of export commitment using subjective measures dealing with managers' behaviors towards exporting. Two items, "we commit significant resources to the export venture" and "management demonstrates strong commitment to the export venture", were adapted from Cavusgil and Zou (1994), and the respondents were asked to evaluate them on a seven-point Likert scale ranging from "strongly disagree" (1) to "strongly agree" (7). We operationalized export experience as a single-item scale using the number of years a firm had engaged in exporting activities (Cadogan, Adamantios, \& Siguaw, 2002; Katsikeas et al., 1996; Navarro et al., 2010a).

Matching: The matching construct, which was introduced by Ghauri and Holstius (1996) in a qualitative manner, required operational definition. We operationalized matching as a second-order construct with two sub-constructs: micro- and macro-level matching activities. Whereas micro-level matching activities refer to networking activities with other business-level actors (i.e. firms, suppliers, and customers), macro-level matching deals with the existence of bilateral agreements between governments, and networking activities with non-business actors (i.e. local governments and consultants), mainly in the dominant export markets. We first 
developed a new item pool, incorporating items relating to micro- and macro-level networking activities. The generation of the items followed recommendations from the scale development literature (Churchill, 1979; Fowler, 1995). They were developed in a joint session by three academic experts, all familiar with the matching concept and the domain of the construct. A total of nine items were produced based on a seven-point Likert scale ranging from "strongly disagree" (1) to "strongly agree" (7).

Export performance: In the study, export performance is assessed using subjective measures in terms of the respondents' satisfaction with the firms' export performance, with a combination of five items that include economic, profit-related, and non-economic measures (Katsikeas, Leonidou, \& Morgan, 2000; Sinkovics, Sinkovics, \& Jean, 2013). Previous research has indicated that export performance must include managerial satisfaction, which provides a benchmark of organizational expectations and affects the selection of future strategies (Navarro et al., 2010b; Shoham, 1998). Respondents were asked to indicate their degree of satisfaction with their export performance on a seven-point Likert scale ranging from "not at all satisfied" (1) to "very satisfied" (7). The items used for measuring export performance were taken from Katsikeas et al. (2000). Additionally, we chose to measure export performance using subjective measures only, in order to avoid biases stemming from the different industry- or market-specific factors and to enable comparison among the responses. Moreover, small export firms are often reluctant to disclose confidential information regarding their financial condition, while it has also been suggested that financial data published for SMEs are very often manipulated either to appear financially strong to the interested parties (shareholders, banks etc.) or to reduce the firm's tax obligations (Brigham \& Ehrhardt, 2002). Finally, firm size was included as a control variable so that we could assess the effect of exporting SMEs' scale on their export performance. Firm size was operationalized as the total sales of the company. Table 1 presents the measurement scales. 


\subsection{Results}

\subsubsection{Descriptive statistics}

The descriptive statistics of the sample firms are presented in Table 2. The engineering sector was most widely represented in the sample, with $31.10 \%$, followed by firms in the textile (10.40\%), chemicals (4.70\%), automotive (3.80\%), and furnishing (2.80\%) industries. Despite a strong bias towards the engineering sector, the generalizability of the sample to the population of firms in the North West region of England is not considered a problem. However, the data will most probably lack generalizability to the UK context overall. The results demonstrate that $59.3 \%$ of the firms are younger than 25 years old. All firms have less than 250 employees, while $73.7 \%$ percent of them have less than 50 full-time employees. The descriptive data also show that $71.8 \%$ percent of the sample firms have less than 20 years of export experience, while more than $50 \%$ have less than 10 years. Overall, our sample reflects small and young entrepreneurial firms, most having limited export experience.

Insert Table 2 around here

\subsubsection{PLS analysis}

We applied PLS-SEM to our data, using the SmartPLS 3 software (Ringle, Wende, \& Becker, 2015). The following features made PLS-SEM the most appropriate data analysis technique for this research. Firstly, PLS-SEM is one of the most appropriate techniques for examining exploratory/predictive research models where the objective is to explain variance (Henseler, Ringle, \& Sinkovics, 2009; Richter, Sinkovics, Ringle, \& Schlägel, 2016). To the best of our knowledge, this is the first study to introduce the matching construct into a conceptual model and test it using quantitative data. We aim to explore previously untested relationships between matching, export barriers, export commitment, and export performance using a 'softmodeling' approach (Wold, 1980). Hence, given its exploratory and theory-building nature, PLSSEM is the most appropriate method for this research. Secondly, we developed a complex model in terms of both the number of relationships and also the inclusion of both direct and moderated effects between constructs, for which PLS offers robust solutions (Hair, Hult, Ringle, \& Sarstedt, 
2017; Kurt, Yamin, Sinkovics, \& Sinkovics, 2016). Finally, with PLS-SEM, the sample size must meet only minimal requirements in order for robust statistical power to be gained (Hair, Sarstedt, Pieper, \& Ringle, 2012; Henseler et al., 2009; Lohmöller, 1989). We have a moderate sample size ( $\mathrm{n}=106)$, but it is sufficient under the 'ten times' rule, which makes PLS-SEM a robust analysis technique for our research (Barclay, Higgins, \& Thompson, 1995; Reinartz, Haenlein, \& Henseler, 2009; Richter et al., 2016). We used a two-stage hierarchical component model (HCM) analysis for the operationalization of the higher-order construct-matching (Hair et al., 2017). We first ran the first-order measurement model in order to obtain latent variable scores for the lowerorder components, which became the observed indicators of the matching construct in the higherorder component measurement model (Becker, Klein, \& Wetzels, 2012). This enabled us to estimate a more parsimonious model in the higher-level analysis. We also applied PLS Mode A as reflective measurements are usually associated with Mode A (Hair et al., 2017).

\subsubsection{Assessment of the measurement model}

We assessed the measurement model with reflective indicators by evaluating reliability and validity. We examined internal reliability using composite reliability (CR). Hair et al. (2017) indicated that PLS does not require all indicators to have equal reliability (as Cronbach's alpha does), which makes CR a more appropriate measure of reliability for the PLS-SEM method. The CR scores were all above 0.8 , ranging from 0.809 to 0.958 , which suggests that the composite measurement items have sufficient reliability (Hair et al., 2017). We also assessed the reliability of each latent variable. Most of the variables explained a substantial part of each indicator's variance, and the correlations between the constructs and each of their manifest variables were at least 0.50 . We followed the minimum cut-off criterion of 0.5 for the indicator's outer loadings (Anderson \& Gerbing, 1988; Hair, Ringle, \& Sarstedt, 2011). The absolute standardized firstorder outer loadings ranged from 0.624 to 0.944 , with most items exceeding the value of 0.7 . One item related to the matching construct was slightly below that threshold, at 0.437 , but for reasons

of internal consistency was retained in the construct scale (see Table 1). A total of eight reflective indicators (five items from export barriers and three items from matching) with very low outer loadings (below 0.40) were dropped from the respective constructs (Bagozzi, Yi, \& Phillips, 1991; Hair et al., 2017). 
To assess the validity of the constructs, we examined convergent and discriminant validity. Convergent validity signifies that the set of indicators represents one and the same underlying construct, and this was assessed following Fornell and Larcker (1981), who suggest that an average variance extracted (AVE) of at least 0.5 indicates sufficient convergent validity. All constructs showed AVE values greater than the 0.5 threshold, ranging from 0.510 to 0.884 , confirming convergent validity (Fornell \& Larcker, 1981). We assessed discriminant validity using the Fornell-Larcker and heterotrait-monotrait (HTMT) criteria. The Fornell-Larcker criterion postulates that a latent variable shares more variance with its assigned indicators than with any other latent variable (Fornell \& Larcker, 1981). As shown in Table 3, since the AVE of each latent variable is greater than the latent variable's highest squared correlation with any other latent variable, discriminant validity is also established. The HTMT ratios of the correlations are part of a new criterion developed by Henseler, Ringle, and Sarstedt (2014) to assess discriminant validity. The HTMT results presented in Table 3 are all below the threshold of 0.90, which again confirms discriminant validity (Hair et al., 2017; Henseler et al., 2014).

\section{Insert Table 3 around here}

\subsubsection{Structural model results and hypothesis testing}

We now proceed with the structural model assessment given the reliable and valid measurement model estimation. The coefficient of determination $\left(R^{2}\right)$ of the endogenous latent variables is a vital element of evaluating the predictive power of the structural model. Chin (1998) describes $R^{2}$ values of 0.67, 0.33, and 0.19 in PLS path models as substantial, moderate, and weak, respectively. The $R^{2}$ value of export performance is 0.453 , indicating the model has a moderate level of predictive power (Chin, 1998; Cohen, 1988; Ringle, Sarstedt, \& Straub, 2012). We assessed the effect size ( $\mathrm{f}^{2}$, the change in $R^{2}$ ) in order to examine the impact of an independent latent variable on a dependent latent variable (Chin, 2010; Hair et al., 2017). $\mathrm{f}^{2}$ values of $0.02,0.15$, and 0.35 are considered small, medium, and large effect sizes (Chin, 2010; Cohen, 1988). The effect sizes of internal barriers, external barriers, export commitment, export experience, and matching on export performance are 0.076, 0.018, 0.197, 0.252, and 0.097, respectively. The results demonstrate medium effect sizes from export commitment and export 
experience to export performance, and small effect sizes from internal barriers, external barriers, and matching to export performance.

We used the bootstrapping technique to test the hypotheses and assess the path coefficients' significance (Hair et al., 2017; Henseler et al., 2009). We ran a 5000 times resampling method of the 106 observations. The path coefficients from internal barriers and external barriers to export performance are $-0.324(\mathrm{t}=2.378, \mathrm{p}<0.05)$ and $0.140(\mathrm{t}=1.222$, n.s. $)$ respectively, which support only $\mathrm{H} 1 \mathrm{a}$. The path coefficient from export commitment to export performance is $0.333(\mathrm{t}=3.449, \mathrm{p}<0.01)$ and those to internal barriers and external barriers are $0.369(\mathrm{t}=4.116, \mathrm{p}<0.001)$ and $-0.300(\mathrm{t}=2.976, \mathrm{p}<0.01)$ respectively, which support $\mathrm{H} 2, \mathrm{H} 3 \mathrm{a}$, and $\mathrm{H} 3 \mathrm{~b}$. The path coefficient from export experience to export performance is $0.146(\mathrm{t}=2.205$, $\mathrm{p}<0.05)$ and those to internal barriers and external barriers are $-0.417(\mathrm{t}=5.752, \mathrm{p}<0.01)$ and $0.256(\mathrm{t}=3.038, \mathrm{p}<0.01)$ respectively, which support H4, H5a, and H5b. The path coefficient from matching to export performance is $0.251(\mathrm{t}=2.231, \mathrm{p}<0.05)$, which supports H6. The results also indicate that matching only significantly moderates the relationship between internal barriers and export performance $(\beta=-0.308, \mathrm{t}=2.371, \mathrm{p}<0.05)$, which confirms H7a. When we controlled for firm size, we found a significant effect $(\beta=0.099)$ on the performance dimension at a 0.05 level of significance. The results of the hypothesis testing are presented in Table 4 and Figure 2 below.

\section{Insert Table 4 and Figure 2 around here}

The results presented in Table 4 and Figure 2 indicate that, out of the moderating relationships, only the moderating effect of matching in connection with internal barriers turns out to significantly alleviate the negative impact of internal barriers on export performance. Moreover, there are significant contributions made by export experience and export commitment in terms of alleviating both the internal and external export barriers perceived by managers. Matching, export experience, and export commitment also directly and significantly contribute to export performance. The findings also reveal that the perceived internal barriers are considered the main impediments to exporting activities in the context of SMEs, whereas external barriers 
have no significant impact on export performance. Finally, we found the size of the firm to have a positive yet small impact on its exporting performance.

\section{Discussion}

Globalization has been driving the IB research field over the past three decades (Meyer, 2017). As highlighted by Buckley (2002), it has been one of the three key research areas successfully tackled in the IB field. Furthermore, Buckley and Ghauri (2004) highlighted globalization as one of the next big questions of IB research. However, in the aftermath of the recent global recession in 2008, globalization is shifting into a different phase, characterized by popular globalization discontents (Stiglitz, 2018) and a gradual increase in protective measures taken by national governments (Bremmer, 2014; Kobrin, 2017; Meyer, 2017). While globalization has benefited the vast majority of the world's population, there have also been losers, mainly the middle class and low-skilled populations in the advanced economies, whose living standards have fallen in both real and nominal terms as a result of a redistribution/transfer of low-knowledge activities to lower-cost locations/emerging markets (Cano-Kollmann et al., 2017; Cuervo-Cazurrra et al., 2017; Rodrik, 2018; Stiglitz, 2018). This discontent experienced by large (middle-class and lower-class) segments of the populations in the global north has fueled nationalist and protectionist movements that have given rise to populist narratives and facilitated the implementation of anti-globalist policies (Cano-Kollmann et al., 2017; Stiglitz, 2018). Similarly, recent studies have highlighted a continuous increase of policy measures and regulations creating less welcoming investment climates and more barriers to cross-border activities, also confirmed by the recent UNCTAD and WTO figures (Kaspar, 2017; Sauvant, 2013; UNCTAD, 2016; WTO, 2016).

Technological advances and institutional changes have been accepted as two main pillars of globalization (Cuervo-Cazurrra et al., 2017). Whereas technological advances such as transportation and electronic communications are likely to progress, institutional changes have started to reverse, moving from pro-globalization back to anti-globalization (ibid). Although policy reversals towards protectionist sentiments are likely to hamper the cross-border activities of both large and small firms, MNEs have sufficient resources to "implement technological workarounds to circumvent anti-globalization policies as well as to lobby successfully against policies that harm their specific interest" (Cano-Kollmann et al., 2017, p.4). Therefore, protective 
nation-centered policies will be particularly deleterious to SMEs and international new ventures, which are active players in export markets (ibid). Hence, managers of these small firms are now challenged to make more careful decisions and find strategies to manage the risks associated with the shift towards a less interconnected global landscape accompanied by increasing skepticism towards free trade.

Not only managers but also IB scholars need to address these vibrant changes and develop a more nuanced understanding of the new developments, structural changes, and uncertainties in the global landscape (Delios, 2017). The influence of these trends on both organizations and societies can be better understood through focusing on specific contexts in which antiglobalization movements are becoming prominent (i.e. Brexit in the UK, Trump in the US, and populist voices in the EU) (Barnett, 2017; Welfens, 2017). In order to be able to provide a strategic roadmap for organizations as to how they might navigate through these uncertainties and ambiguities, light needs to be shed on effective mechanisms that firms, particularly SMEs, can use to reduce the negative impact of potential impediments to trade and economic integration arising from the current uncertainties. We put forward that matching activities with business and particularly non-business actors (i.e. governments) can help SMEs significantly in overcoming export barriers and facilitate their exporting ambitions. Moving forward from a period where globalization was the dominant mantra towards trading relationships that are likely increasing in complexity, export barriers and uncertainties, this research has focused on a contemporary context. A consensus exists that Brexit will unleash fundamental changes in the British business environment, which will in turn alter the dynamics of relationships with the rest of the world and thus lead to massive uncertainty in the markets in the UK and around the world (Cumming \& Zahra, 2016). Hence, the matching concept may offer strategic guidance for exporting SMEs to ensure their exporting activities survive in an era where markets are becoming more isolated and protected by governments.

Our paper contributes to the IB and IE literatures. Globalization, and the networks created as its by-product, have been considered an effective mechanism facilitating entrepreneurship (Prashantham, Eranova, \& Couper, 2017). Entrepreneurship is thus now under threat from backlashes against globalization. With the rise of protectionist and nationalist policies, institutions, which provide the basic framework within which entrepreneurs make decisions, are becoming subject to significant change, which could in turn create institutional voids (Cumming 
\& Zahra, 2016). While firms and managers are likely to face uncertainties and delays in business decisions, these voids might also create business opportunities for entrepreneurs (Cumming \& Zahra, 2016). However, as indicated by previous empirical research, the identification and exploitation of these market opportunities in different countries, and the bridging of institutional voids across locations, will very much depend on the networking capabilities of the entrepreneurs (Coviello \& Munro, 1995; Gillian \& Jay, 2006; Oviatt \& McDougall, 2005). Therefore, entrepreneurial firms, in order to overcome institutional constraints and exploit opportunities, need to develop dynamic networking capabilities through active involvement in relationships with business and non-business actors (Cumming \& Zahra, 2016; Gillian \& Jay, 2006). In this vein, matching can operate as an appropriate concept for understanding how entrepreneurial firms can use multiple levels of networking activities to overcome barriers as well as identify/exploit opportunities. For instance, Cumming and Zahra (2016) discussed that the institutional upheaval and uncertainties resulting from Brexit are likely to reduce the number of institutional investors available to UK entrepreneurs, as such investors are likely to flow to other attractive locations. In this context, macro-level networking activities with local governments or political actors might help UK entrepreneurs to secure government loans.

The highlights of our findings are as follows. Firstly, matching, which emphasizes the micro and macro levels of networking activities, shows a significant impact in terms of alleviating the negative impact of internal barriers on export performance, in addition to its direct positive impact on performance. This finding provides empirical evidence of the critical role of matching in the international success of SMEs and entrepreneurial firms. The results demonstrate that the main effect of matching is to alleviate the perceived internal barriers, such as difficulties exploiting foreign opportunities and lack of foreign market knowledge, for SMEs and entrepreneurs that export to international markets. For SMEs that lack substantial information regarding foreign markets, micro and macro matching can help them to exchange information and resources with different actors and thus to achieve a better position in an international market (Elg, 2008; Elg et al., 2008). Matching activities can generate valuable market information and in-depth understanding of customer needs as well as institutional and cultural contexts (Elg et al., 2008; Ghauri \& Holstius, 1996). These findings are also in line with previous findings demonstrating the importance of political and institutional ties as a key resource for 
organizations, which can gain support from non-business actors when entering and operating in foreign markets (Frynas et al., 2006; Lu et al., 2010; Peng \& Luo, 2000).

However, our results do not find support for the notion of matching reducing firms' external export barriers. This result may be due to the managers' perceptions about the insignificant impact of external barriers on firms' exporting performance. In the context of SMEs, managers might perceive the internal barriers to be the main impediments to their exporting activities. Our findings also demonstrate that internal barriers have significant negative impacts on export performance, whereas external barriers are not considered significant for export performance. Hence, matching activities may be treated primarily as mechanisms through which firms can overcome their liability of smallness and lack of resources, by managers who see internal barriers as the key obstacle to exporting.

Secondly, the results confirm the important impact export commitment has on both the perceived internal and external export barriers and export performance. It operates as a direct determinant of the managers' satisfaction with export performance, which is in line with previous research that has indicated export commitment to be an important determinant of the international success of export firms (Aaby \& Slater, 1989; Cavusgil \& Zou, 1994; Navarro et al., 2010b). A key way in which export commitment may foster export performance may be that it enables the effective implementation of a resource-led strategy (Navarro et al., 2010a). Despite the lack of sufficient resources among SMEs, export commitment can provide strategic guidelines such that they adequately and efficiently allocate their available limited resources to exporting activities. Moreover, whereas prior work has mostly identified export commitment as a determinant of success in foreign markets, we develop a direct link from commitment to export performance outcomes, for a more exact understanding (Lages, Jap, \& Griffith, 2008; Navarro et al., 2010a). The findings also show that export commitment indirectly contributes to export performance through a reduction of managers perceived internal and external export barriers. Highly committed managers are likely to perceive the barriers to their exporting activities less intensively, which might also affect their satisfaction with the achievement of their export performance objectives in foreign markets.

Finally, we found a positive and significant relationship between export experience and export performance, which is in line with previous research that found a positive impact of firms' 
international experience on their internationalization/exporting performance (see Clarke, Tamaschke, \& Liesch, 2013 for a comprehensive review; Love et al., 2016). International experience has been considered a key element in explaining foreign market success. For instance, Clarke et al. (2013, p.265) indicated that "the concept of international experience plays a leading role in explaining firm internationalization". We also found negative relationships from export experience to internal and external export barriers, confirming that experience reduces the level of export barriers perceived by the managers. This finding is in line with previous research suggesting that experience gained through exposure to international markets helps firms, particularly SMEs, to overcome the difficulties of doing business in foreign markets (Katsikeas et al., 1996; Westhead, Wright, \& Ucbasaran, 2001). Through their foreign market activities, firms can develop experiential knowledge/learning, which in turn reduces managerial uncertainties (Johanson \& Vahlne, 2003, 2009).

\section{Conclusion, limitations, and future research}

Previous studies have pointed at the role of networks in enabling firms to overcome exporting and internationalization barriers (Chetty \& Blankenburg Holm, 2000; Coviello, 2006; Shoham \& Albaum, 1995; Zhou et al., 2007). However, previous research has mostly studied micro- or macro-level networking activities separately. This study offers an in-depth understanding of the role of networking activities, by incorporating the matching concept, which deals with micro- and macro-level networks, into the export marketing literature. Our empirical findings demonstrate that matching significantly alleviates the perceived internal export barriers, which are a key obstacle to exporting in our empirical analysis.

The results clearly show the importance of developing and orchestrating network relationships with multiple actors at different levels in order to overcome export barriers. Contemporary structural and institutional changes in the IB environment, culminating in popular globalization discontents, are likely to create additional uncertainties and barriers for internationalizing firms. IB scholarship can help in understanding potential strategies that export firms may take in order to survive and successfully compete.

The findings of this study offer important managerial implications, particularly for owners/managers of small firms who develop export strategies against an increasingly nationalistic context. Protectionist policies can significantly hurt export activities and put national 
economies at risk - particularly those with high exports-to-GDP ratios (e.g. Luxembourg, Singapore, Ireland, and the Netherlands) (Ghemawat, 2017). While companies and managers are reevaluating their export strategies in the light of today's anti-globalization sentiments, they should reconsider the depth and breadth of their networking activities with different actors in multiple markets. Given the role of matching in alleviating internal barriers, it is thus particularly important for SMEs, which are likely to experience more internal barriers as an outcome of their liability of smallness compared to large MNEs, to develop relationships with multiple business and non-business actors in both home and host markets. Matching activities can help them to overcome internal barriers and improve foreign market-expansion success.

As with any study, our research findings should be interpreted keeping some limitations in mind. First, the sample was restricted to firms within the UK. Replications of this study in other countries, such as emerging countries, where state capitalism further distorts liberal market ideas, may offer interesting variegated findings. A larger sample size might also be fruitful. Second, this study concentrates on export commitment, export experience, and matching as the exporting facilitators. Other potential determinants, such as using the internet to reduce export barriers and enhance export performance, should be considered in future studies. As we discussed earlier, technological advances, as one driver of globalization, could be exploited to overcome the uncertainties coming from institutional change. Third, although this study firmly responds to the call for further systematic research on matching, by following a causal approach (Elg et al., 2008), the cross-sectional nature of the study limits our understanding of how and to what extent matching activities affect performance outcomes at different phases of foreign market entry. Additionally, it would be important to measure the level and intensity of globalization discontent challenges explicitly and operationalize these in the questionnaire. In our study this is only a context variable. Finally, this is the first, and a timely, empirical attempt to develop a measurement scale of the matching construct, which could contribute considerably to future research aiming to develop a more comprehensive network understanding of exporting and internationalization. Building on our construct, future research strengthening the matching scale through the addition of new items relating to micro and macro level activities may be particularly fruitful. 


\section{References}

Aaby, N. E., \& Slater, S. F. (1989). Management influences on export performance: A review of the empirical literature 1978 - 1988. International Marketing Review, 6(4), 7-26. doi: 10.1108/EUM0000000001516

Altıntaş, M. H., Tokol, T., \& Harcar, T. (2007). The effects of export barriers on perceived export performance: An empirical research on SMEs in Turkey. EuroMed Journal of Business, 2(1), 36-56. doi: 10.1108/14502190710749947

Anderson, J. C., \& Gerbing, D. W. (1988). Structural equation modeling in practice: A review and recommended two-step approach. Psychological bulletin, 103(3), 411-423. doi: 10.1037/0033-2909.103.3.411

Armstrong, J. S., \& Overton, T. S. (1977). Estimating nonresponse bias in mail surveys. Journal of Marketing Research, 14(3), 396-402. doi: 10.2307/3150783

Arteaga-Ortiz, J., \& Fernández-Ortiz, R. (2010). Why don't we use the same export barrier measurement scale? An empirical analysis in small and medium-sized enterprises.

Journal of Small Business Management, 48(3), 395-420. doi: 10.1111/j.1540627X.2010.00300.x

Babakus, E., Yavas, U., \& Haahti, A. (2006). Perceived uncertainty, networking and export performance: A study of nordic SMEs. European Business Review, 18(1), 4-13. doi: $10.1108 / 09555340610639815$

Bagozzi, R. P., Yi, Y., \& Phillips, L. W. (1991). Assessing construct validity in organizational research. Administrative Science Quarterly, 36(3), 421-458. doi: 10.2307/2393203

Barclay, D., Higgins, C., \& Thompson, R. (1995). The partial least squares (PLS) approach to causal modeling: Personal computer adoption and use as an illustration. Technology studies, 2(2), 285-309.

Barnett, A. (2017). Lure of greatness : England's brexit \& america's trump. London: Unbound.

Baruch, Y., \& Holtom, B. C. (2008). Survey response rate levels and trends in organizational research. Human Relations, 61(8), 1139-1160. doi: 10.1177/0018726708094863

Becker, J.-M., Klein, K., \& Wetzels, M. (2012). Hierarchical latent variable models in PLS-SEM: Guidelines for using reflective-formative type models. Long Range Planning, 45(5-6), 359-394. doi: 10.1016/j.lrp.2012.10.001

Bloemer, J., Pluymaekers, M., \& Odekerken, A. (2013). Trust and affective commitment as energizing forces for export performance. International Business Review, 22(2), 363-380. doi: 10.1016/j.ibusrev.2012.05.002

Bremmer, I. (2014). The new rules of globalization. Harvard Business Review, 92(1), 103-107.

Brigham, F. E., \& Ehrhardt, C. M. (2002). Financial management: Theory and practice: South Western - Thomson Learning.

Buckley, P. J. (2002). Is the international business research agenda running out of steam? Journal of International Business Studies, 33(2), 365-373. doi: 10.1057/palgrave.jibs.8491021

Buckley, P. J., \& Ghauri, P. N. (2004). Globalisation, economic geography and the strategy of multinational enterprises. Journal of International Business Studies, 35(2), 81-98. doi: 10.1057/palgrave.jibs.8400076

Cadogan, J., W., Adamantios, D., \& Siguaw, J. A. (2002). Export market-oriented activities: Their antecedents and performance consequences. Journal of International Business Studies, 33(3), 615-626.

Calantone, R. J., Kim, D., Schmidt, J. B., \& Cavusgil, S. T. (2006). The influence of internal and external firm factors on international product adaptation strategy and export performance: 
A three-country comparison. Journal of Business Research, 59(2), 176-185. doi: 10.1016/j.jbusres.2005.05.001

Cano-Kollmann, M., Hannigan, T. J., \& Mudambi, R. (2017). Global innovation networks organizations and people. Journal of International Management, Advance online publication. doi: 10.1016/j.intman.2017.09.008

Carrier, C. (1999). The training and development needs of owner-managers of small businesses with export potential. Journal of Small Business Management, 37(4), 30-42.

Cavusgil, S. T. (1984). Organizational characteristics associated with export activity. The Journal of Management Studies, 21(1), 3-22. doi: 10.1111/j.1467-6486.1984.tb00222.x

Cavusgil, S. T., \& Knight, G. (2015). The born global firm: An entrepreneurial and capabilities perspective on early and rapid internationalization. Journal of International Business Studies, 46(1), 3-16. doi: 10.1057/jibs.2014.62

Cavusgil, S. T., \& Nevin, J. R. (1981). Internal determinants of export marketing behavior: An empirical investigation. Journal of Marketing Research, 18(1), 114-119. doi: $10.2307 / 3151322$

Cavusgil, S. T., \& Zou, S. (1994). Marketing strategy-performance relationship: An investigation of the empirical link in export market ventures. The Journal of Marketing, 58(1), 1-21. doi: $10.2307 / 1252247$

Chetty, S., \& Blankenburg Holm, D. (2000). Internationalisation of small to medium-sized manufacturing firms: A network approach. International Business Review, 9(1), 77-93. doi: 10.1016/S0969-5931(99)00030-X

Chetty, S. K., \& Wilson, H. I. M. (2003). Collaborating with competitors to acquire resources. International Business Review, 12(1), 61-81. doi: 10.1016/S0969-5931(02)00088-4

Chidlow, A., Ghauri, P. N., Yeniyurt, S., \& Cavusgil, S. T. (2015). Establishing rigor in mailsurvey procedures in international business research. Journal of World Business, 50(1), 26-35. doi: 10.1016/j.jwb.2014.01.004

Chin, W. W. (1998). The partial least squares approach to structural equation modelling. In G. A. Marcoulides (Ed.), Modern methods for business research (pp. 295-358). Mahwah, NJ: Lawrence Erlbaum Associates

Chin, W. W. (2010). How to write up and report PLS analyses. In V. Esposito Vinzi, W. W. Chin, J. Henseler \& H. Wang (Eds.), Handbook of partial least squares: Concepts, methods and applications (pp. 655-690). Berlin, Heidelberg: Springer. doi:10.1007/978-3540-32827-8_29

Churchill, G. A. (1979). A paradigm for developing better measures of marketing constructs. Journal of Marketing Research, 16(1), 64-73. doi: 10.2307/3150876

Clarke, J. E., Tamaschke, R., \& Liesch, P. W. (2013). International experience in international business research: A conceptualization and exploration of key themes. International Journal of Management Reviews, 15(3), 265-279. doi: 10.1111/j.1468-2370.2012.00338.x

Cohen, J. (1988). Statistical power analysis for the behavioral sciences. Hillsdale, N.J.: L. Erlbaum Associates.

Coviello, N., \& Munro, H. (1995). Growing the entrepreneurial firm: Networking for international market development. European Journal of Marketing, 29(7), 243-253. doi: $10.1108 / 03090569510095008$

Coviello, N. E. (2006). The network dynamics of international new ventures. Journal of International Business Studies, 37(5), 713-731. doi: 10.1057/palgrave.jibs.8400219

Cuervo-Cazurrra, A., Mudambi, R., \& Pedersen, T. (2017). Globalization: Rising skepticism. Global Strategy Journal, 7(2), 155-158. doi: 10.1002/gsj.1156 
Cumming, D. J., \& Zahra, S. A. (2016). International business and entrepreneurship implications of brexit. British Journal of Management, 27(4), 687-692. doi: 10.1111/1467-8551.12192

Dean, D. L., Mengüç, B., \& Myers, C. P. (2000). Revisiting firm characteristics, strategy, and export performance relationship:: A survey of the literature and an investigation of new zealand small manufacturing firms. Industrial Marketing Management, 29(5), 461-477. doi: 10.1016/S0019-8501(99)00085-1

Delios, A. (2017). The death and rebirth (?) of international business research. Journal of Management Studies, 54(3), 391-397. doi: 10.1111/joms.12222

Demick, D. H., \& O'Reilly, A. J. (2000). Supporting SME internationalisation: A collaborative project for accelerated export development. Irish Marketing Review, 13(1), 34-45.

Dhanaraj, C., \& Beamish, P. W. (2003). A resource-based approach to the study of export performance. Journal of Small Business Management, 41(3), 242-261. doi: 10.1111/1540$627 X .00080$

Dickson, A. (2013). Development and international relations: A critical introduction. Cambridge: Polity Press.

Dillman, D. A., Smyth, J. D., \& Leah, C. M. (2014). Internet, phone, mail, and mixed-mode surveys: The tailored design method (4th ed.). Hoboken: Wiley.

Doh, J. P., Lawton, T. C., \& Rajwani, T. (2012). Advancing nonmarket strategy research: Institutional perspectives in a changing world. Academy of Management Perspectives, 26(3), 22-39. doi: 10.5465/amp.2012.0041

Donckels, R., \& Lambrecht, J. (1997). The network position of small businesses: An explanatory model. Journal of Small Business Management, 35(2), 13-25.

Donthu, N., \& Kim, S. H. (1993). Implications of firm controllable factors on export growth. Journal of Global Marketing, 7(1), 47-64. doi: 10.1300/J042v07n01_04

Elg, U. (2008). Inter-firm market orientation and the influence of network and relational factors. Scandinavian Journal of Management, 24(1), 55-68. doi: 10.1016/j.scaman.2007.08.001

Elg, U., Ghauri, P. N., \& Tarnovskaya, V. (2008). The role of networks and matching in market entry to emerging retail markets. International Marketing Review, 25(6), 674-699. doi: $10.1108 / 02651330810915583$

Elg, U., \& Johansson, U. (1996). Networking when national boundaries dissolve. European Journal of Marketing, 30(2), 61-74. doi: 10.1108/03090569610106653

Ellis, P. (2000). Social ties and foreign market entry. Journal of International Business Studies, 31(3), 443-469. doi: 10.1057/palgrave.jibs.8490916

Emerson, R. (1962). Power dependence relations. American Sociological Review, 27(1), 31-41. doi: $10.2307 / 2089716$

Forlani, D., Parthasarathy, M., \& Keaveney, S. M. (2008). Managerial risk perceptions of international entry - mode strategies: The interaction effect of control and capability. International Marketing Review, 25(3), 292-311. doi: 10.1108/02651330810877225

Fornell, C., \& Larcker, D. F. (1981). Evaluating structural equation models with unobservable variables and measurement error. Journal of Marketing Research, 18(1), 39-50. doi: $10.2307 / 3151312$

Forsgren, M. (2002). The concept of learning in the Uppsala internationalization process model: A critical review. International Business Review, 11(3), 257-277. doi: 10.1016/S09695931(01)00060-9

Fowler, F. J. (1995). Improving survey questions: Design and evaluation (Vol. 38). Thousand Oaks, Ca.: Sage Publications. 
Frynas, J. G., Mellahi, K., \& Pigman, G. A. (2006). First mover advantages in international business and firm-specific political resources. Strategic Management Journal, 27(4), 321345. doi: $10.1002 / \mathrm{smj} .519$

Ghauri, P. N., \& Holstius, K. (1996). The role of matching in the foreign market entry process in the baltic states. European Journal of Marketing, 30(2), 75-88. doi: 10.1108/03090569610106671

Ghauri, P. N., Lutz, C., \& Tesfom, G. (2003). Using networks to solve export-marketing problems of small- and medium-sized firms from developing countries. European Journal of Marketing, 37(5/6), 728-752. doi: 10.1108/03090560310465125

Ghemawat, P. (2017). Globalization in the age of trump. Harvard Business Review, 95(4), 112123.

Gillian, S. M., \& Jay, W. (2006). Networking capability and international entrepreneurship: How networks function in Australian born global firms. International Marketing Review, 23(5), 549-572. doi: 10.1108/02651330610703445

Golovko, E., \& Valentini, G. (2011). Exploring the complementarity between innovation and export for SMEs' growth. Journal of International Business Studies, 42(3), 362-380. doi: 10.1057/jibs.2011.2

Hadjikhani, A., \& Ghauri, P. N. (2001). The behaviour of international firms in socio-political environments in the european union. Journal of Business Research, 52(3), 263-275. doi: 10.1016/S0148-2963(99)00106-X

Hadjikhani, A., Lee, J.-W., \& Ghauri, P. N. (2008). Network view of MNCs' socio-political behavior. Journal of Business Research, 61(9), 912-924. doi: 10.1016/j.jbusres.2007.10.001

Hair, J. F., Hult, G. T. M., Ringle, C. M., \& Sarstedt, M. (2017). A primer on partial least squares structural equation modeling (PLS-SEM) (2nd ed.). Thousands Oak, CA: Sage Publications.

Hair, J. F., Ringle, C. M., \& Sarstedt, M. (2011). PLS-SEM: Indeed a silver bullet. Journal of Marketing Theory and Practice, 19(2), 139-152. doi: 10.2753/MTP1069-6679190202

Hair, J. F., Sarstedt, M., Pieper, T. M., \& Ringle, C. M. (2012). The use of partial least squares structural equation modeling in strategic management research: A review of past practices and recommendations for future applications. Long Range Planning, 45(5), 320-340. doi: 10.1016/j.lrp.2012.09.008

Helleiner, E., \& Pickel, A. (2005). Economic nationalism in a globalizing world. Ithaca, N.Y.: Cornell University Press.

Henseler, J., Ringle, C. M., \& Sarstedt, M. (2014). A new criterion for assessing discriminant validity in variance-based structural equation modeling. Journal of the Academy of Marketing Science, 43(1), 115-135. doi: 10.1007/s11747-014-0403-8

Henseler, J., Ringle, C. M., \& Sinkovics, R. R. (2009). The use of partial least squares path modeling in international marketing New challenges to international marketing (pp. 277319). doi:10.1108/S1474-7979(2009)0000020014

Hillman, A. J., Keim, G. D., \& Schuler, D. (2004). Corporate political activity: A review and research agenda. Journal of Management, 30(6), 837-857. doi: 10.1016/j.jm.2004.06.003

Holm, D. B., Eriksson, K., \& Johanson, J. (1999). Creating value through mutual commitment to business network relationships. Strategic Management Journal, 20(5), 467-486.

Javalgi, R. G., Griffith, D. A., \& White, D. S. (2003). An empirical examination of factors influencing the internationalization of service firms. The Journal of Services Marketing, 17(2/3), 185-200. doi: 10.1108/08876040310467934 
Johanson, J., \& Vahlne, J.-E. (1977). The internationalization process of the firm-a model of knowledge development and increasing foreign market commitments. Journal of International Business Studies, 8(1), 23-32. doi: 10.1057/palgrave.jibs.8490676

Johanson, J., \& Vahlne, J.-E. (1990). The mechanism of internationalisation. International Marketing Review, 7(4), 11-24. doi: 10.1108/02651339010137414

Johanson, J., \& Vahlne, J.-E. (2003). Business relationship learning and commitment in the internationalization process. Journal of International Entrepreneurship, 1(1), 83-101. doi: 10.1023/A:1023219207042

Johanson, J., \& Vahlne, J.-E. (2009). The Uppsala internationalization process model revisited: From liability of foreignness to liability of outsidership. Journal of International Business Studies, 40(9), 1411-1431. doi: 10.1057/jibs.2009.24

Julien, P.-A., \& Ramangalahy, C. (2003). Competitive strategy and performance of exporting SMEs: An empirical investigation of the impact of their export information search and competencies. Entrepreneurship Theory and Practice, 27(3), 227-245. doi: 10.1111/15408520.t01-1-00002

Kahiya, E. T., Dean, D. L., \& Heyl, J. (2014). Export barriers in a changing institutional environment: A quasi-longitudinal study of new zealand's manufacturing exporters. Journal of International Entrepreneurship, 12(4), 331-364. doi: 10.1007/s10843-0140131-7

Kaspar, M. (2017). The role of aib and ib in a de-globalizing world. AIB Insights, 17(4).

Katsikeas, C. S., Leonidou, L. C., \& Morgan, N. A. (2000). Firm-level export performance assessment: Review, evaluation, and development. Journal of the Academy of Marketing Science, 28(4), 493. doi: 10.1177/0092070300284003

Katsikeas, C. S., \& Morgan, R. E. (1994). Differences in perceptions of exporting problems based on firm size and. European Journal of Marketing, 28(5), 17-35. doi: 10.1108/0309056941006201

Katsikeas, C. S., Piercy, N. F., \& Ioannidis, C. (1996). Determinants of export performance in a european context. European Journal of Marketing, 30(6), 6-35. doi: 10.1108/03090569610121656

Keohane, R. O., \& Nye, J. S. (2000). Globalization: What's new? What's not? (and so what?). Foreign Policy(118), 104-119. doi: 10.2307/1149673

Kiss, A. N., \& Danis, W. M. (2010). Social networks and speed of new venture internationalization during institutional transition: A conceptual model. Journal of International Entrepreneurship, 8(3), 273-287. doi: 10.1007/s10843-010-0051-0

Kobrin, S. J. (2017). Bricks and mortar in a borderless world: Globalization, the backlash, and the multinational enterprise. Global Strategy Journal, 7(2), 159-171. doi: 10.1002/gsj.1158

Kurt, Y., \& Yamin, M. (2016). Understanding internationalisation through the lens of social network analysis. In H. Tüselmann, S. Buzdugan, Q. Cao, D. Freund \& S. Golesorkhi (Eds.), Impact of international business: Challenges and solutions for policy and practice (pp. 241-264). London: Palgrave Macmillan UK. doi:10.1007/978-1-137-56946-2_14

Kurt, Y., Yamin, M., Sinkovics, N., \& Sinkovics, R. R. (2016). Spirituality as an antecedent of trust and network commitment: The case of anatolian tigers. European Management Journal, 34(6), 686-700. doi: 10.1016/j.emj.2016.06.011

Lages, L. F., Jap, S. D., \& Griffith, D. A. (2008). The role of past performance in export ventures: A short-term reactive approach. Journal of International Business Studies, 39(2), 304-325. doi: 10.1057/palgrave.jibs.8400339 
Lages, L. F., \& Montgomery, D. B. (2004). Export performance as an antecedent of export commitment and marketing strategy adaptation: Evidence from small and medium - sized exporters. European Journal of Marketing, 38(9/10), 1186-1214. doi: doi:10.1108/03090560410548933

Leelapanyalert, K., \& Ghauri, P. (2006). Managing international market entry strategy: The case of retailing firms. In A. Rialp \& J. Rialp (Eds.), Advances in international marketing opportunities and challenges in the 21st century (Vol. Volume 17, pp. 193-215). Amsterdam: Elsevier - JAI

Leonidou, C. L. (1995). Empirical research on export barriers: Review, assessment, and synthesis. Journal of International Marketing, 3(1), 29-43.

Leonidou, C. L. (2004a). An analysis of the barriers hindering small business export development. Journal of Small Business Management, 42(3), 279-302.

Leonidou, C. L., \& Katsikeas, S. C. (1996). The export development process: An integrative review of empirical models. Journal of International Business Studies, 27(3), 517-529. doi: $10.1057 /$ palgrave.jibs.8490846

Leonidou, L. C. (2000). Barriers to export management: An organizational and internationalization analysis. Journal of International Management, 6(2), 121-148. doi: 10.1016/S1075-4253(00)00022-3

Leonidou, L. C. (2004b). An analysis of the barriers hindering small business export development. Journal of Small Business Management, 42(3), 279-302. doi: 10.1111/j.1540-627X.2004.00112.x

Li, H., \& Zhang, Y. (2007). The role of managers' political networking and functional experience in new venture performance: Evidence from China's transition economy. Strategic Management Journal, 28(8), 791-804. doi: 10.1002/smj.605

Loane, S., \& Bell, J. (2006). Rapid internationalisation among entrepreneurial firms in Australia, Canada, ireland and new zealand: An extension to the network approach. International Marketing Review, 23(5), 467-485. doi: 10.1108/02651330610703409

Lohmöller, J.-B. (1989). Latent variable path modeling with partial least squares. Heidelberg: Springer

Love, J. H., Roper, S., \& Zhou, Y. (2016). Experience, age and exporting performance in UK SMEs. International Business Review, 25(4), 806-819. doi: 10.1016/j.ibusrev.2015.10.001

Lu, J. W., \& Beamish, P. W. (2006). SME internationalization and performance: Growth vs. Profitability. Journal of International Entrepreneurship, 4(1), 27-48. doi: 10.1007/s10843-006-8000-7

Lu, Y., Zhou, L., Bruton, G., \& Li, W. (2010). Capabilities as a mediator linking resources and the international performance of entrepreneurial firms in an emerging economy. Journal of International Business Studies, 41(3), 419-436. doi: 10.1057/jibs.2009.73

Madsen, T. K. (1998). Managerial judgment of export performance. Journal of International Marketing, 6(3), 82-93.

Manolova, T. S., Manev, I. M., \& Gyoshev, B. S. (2010). In good company: The role of personal and inter-firm networks for new-venture internationalization in a transition economy. Journal of World Business, 45(3), 257-265. doi: 10.1016/j.jwb.2009.09.004

Mark, P., \& Quinn, B. (2005). Stakeholder relationships in an international retailing context: An investment bank perspective. European Journal of Marketing, 39(9/10), 1096-1117. doi: 10.1108/03090560510610743 
McNaughton, R. B. (2003). The number of export markets that a firm serves: Process models versus the born-global phenomenon. Journal of International Entrepreneurship, 1(3), 297-311. doi: 10.1023/A:1024114907150

Meyer, K. (2017). International business in an era of anti-globalization. Multinational Business Review, 25(2), 78-90. doi: 10.1108/MBR-03-2017-0017

Meyer, K. E. (2001). Institutions, transaction costs, and entry mode choice in eastern Europe. Journal of International Business Studies, 32(2), 357-367. doi: 10.1057/palgrave.jibs.8490957

Moini, A. H. (1997). Barriers inhibiting export performance of small and medium-sized manufacturing firms. Journal of Global Marketing, 10(4), 67-93. doi: 10.1300/J042v10n04_05

Morgan, N. A., Kaleka, A., \& Katsikeas, C. S. (2004). Antecedents of export venture performance: A theoretical model and empirical assessment. Journal of Marketing, 68(1), 90-108. doi: 10.1509/jmkg.68.1.90.24028

Morgan, R. E. (1997). Export stimuli and export barriers: Evidence from empirical research studies. European Business Review, 97(2), 68-79. doi: 10.1108/09555349710162571

Musteen, M., Francis, J., \& Datta, D. K. (2010). The influence of international networks on internationalization speed and performance: A study of Czech SMEs. Journal of World Business, 45(3), 197-205. doi: 10.1016/j.jwb.2009.12.003

Navarro, A., Acedo, F. J., Robson, M. J., Ruzo, E., \& Losada, F. (2010a). Antecedents and consequences of firms' export commitment: An empirical study. Journal of International Marketing, 18(3), 41-61. doi: 10.1509/jimk.18.3.41

Navarro, A., Losada, F., Ruzo, E., \& Díez, J. A. (2010b). Implications of perceived competitive advantages, adaptation of marketing tactics and export commitment on export performance. Journal of World Business, 45(1), 49-58. doi: 10.1016/j.jwb.2009.04.004

Nummela, N., Saarenketo, S., \& Puumalainen, K. (2004). A global mindset - a prerequisite for successful internationalization? Canadian Journal of Administrative Sciences / Revue Canadienne des Sciences de l'Administration, 21(1), 51-64. doi: 10.1111/j.19364490.2004.tb00322.x

Nye, J. (2002). Globalism versus globalization. the Globalist. Retrieved April 15, 2016, from https://www.theglobalist.com/globalism-versus-globalization/

Ojala, A. (2009). Internationalization of knowledge-intensive SMEs: The role of network relationships in the entry to a psychically distant market. International Business Review, 18(1), 50-59. doi: 10.1016/j.ibusrev.2008.10.002

Oviatt, B. M., \& McDougall, P. P. (2005). Defining international entrepreneurship and modeling the speed of internationalization. Entrepreneurship Theory and Practice, 29(5), 537-554. doi: 10.1111/j.1540-6520.2005.00097.x

Peng, M. W., \& Luo, Y. (2000). Managerial ties and firm performance in a transition economy: The nature of a micro-macro link. The Academy of Management Journal, 43(3), 486-501. doi: $10.2307 / 1556406$

Peng, M. W., \& Zhou, J. Q. (2005). How network strategies and institutional transitions evolve in Asia. Asia Pacific Journal of Management, 22(4), 321-336. doi: 10.1007/s10490-0054113-0

Piercy, N. F., Kaleka, A., \& Katsikeas, C. S. (1998). Sources of competitive advantage in high performing exporting companies. Journal of World Business, 33(4), 378-393. doi: 10.1016/S1090-9516(99)80081-9 
Pinho, J. C., \& Martins, L. (2010). Exporting barriers: Insights from portuguese small- and medium-sized exporters and non-exporters. Journal of International Entrepreneurship, 8(3), 254-272. doi: 10.1007/s10843-010-0046-x

Podsakoff, P. M., \& Organ, D. W. (1986). Self-reports in organizational research: Problems and prospects. Journal of Management, 12(4), 531-544. doi: 10.1177/014920638601200408

Prashantham, S., Eranova, M., \& Couper, C. (2017). Globalization, entrepreneurship and paradox thinking. Asia Pacific Journal of Management, 35(1), 1-9. doi: 10.1007/s10490-0179537-9

Reinartz, W., Haenlein, M., \& Henseler, J. (2009). An empirical comparison of the efficacy of covariance-based and variance-based SEM. International Journal of Research in Marketing, 26(4), 332-344. doi: 10.1016/j.ijresmar.2009.08.001

Richter, N. F., Sinkovics, R. R., Ringle, C. M., \& Schlägel, C. (2016). A critical look at the use of SEM in international business research. International Marketing Review, 33(3), 376-404. doi: 10.1108/IMR-04-2014-0148

Ringle, C. M., Sarstedt, M., \& Straub, D. (2012). Editor's comments: A critical look at the use of PLS-SEM in MIS quarterly. MIS Quarterly (MISQ), 36(1), iii-xiv.

Ringle, C. M., Wende, S., \& Becker, J.-M. (2015). Smartpls 3. Boenningstedt, Germany: SmartPLS GmbH.

Rodrik, D. (2018). Straight talk on trade: Ideas for a sane world economy. Princeton, New Jersey: Princeton University Press.

Rogelberg, S. G., \& Stanton, J. M. (2007). Introduction: Understanding and dealing with organizational survey nonresponse. Organizational Research Methods, 10(2), 195-209. doi: doi:10.1177/1094428106294693

Rose, G. M., \& Shoham, A. (2002). Export performance and market orientation: Establishing an empirical link. Journal of Business Research, 55(3), 217-225. doi: 10.1016/S01482963(00)00139-9

Rueda-Cantuche, J., \& Sousa, N. (2016). Eu exports to the world: Overview of effects on employment and income: Directorate General for Trade, European Commission.

Ruzzier, M., Antoncic, B., Hisrich, R. D., \& Konecnik, M. (2007). Human capital and SME internationalization: A structural equation modeling study. Canadian Journal of Administrative Sciences, 24(1), 15-29. doi: 10.1002/cjas.3

Sauvant, K. (2013). The rise of FDI protectionism. Columbia FDI Perspectives. from http://ccsi.columbia.edu/files/2013/12/sauvant_rise.pdf

Shaoming Zou, \& Cavusgil, S. T. (2002). The gms: A broad conceptualization of global marketing strategy and its effect on firm performance. Journal of Marketing, 66(4), 4056. doi: $10.1509 / \mathrm{jmkg} .66 .4 .40 .18519$

Sharma, D. D., \& Blomstermo, A. (2003). The internationalization process of born globals: A network view. International Business Review, 12(6), 739-753. doi: 10.1016/j.ibusrev.2003.05.002

Shoham, A. (1998). Export performance: A conceptualization and empirical assessment. Journal of International Marketing, 6(3), 59-81.

Shoham, A., \& Albaum, G. S. (1995). Reducing the impact of barriers to exporting: A managerial perspective. Journal of International Marketing, 3(4), 85-105.

Silva, P. A. d., \& Rocha, A. d. (2001). Perception of export barriers to mercosur by Brazilian firms. International Marketing Review, 18(6), 589-611. doi: 10.1108/EUM0000000006296 
Silverman, M., Sengupta, S., \& Castaldi, R. M. (2004). Improving export performance; the case of the U.S. Wine industry. Journal of Global Marketing, 17(1), 45-65. doi:

10.1300/J042v17n01_04

Sinkovics, N., Sinkovics, R. R., \& Jean, R. J. B. (2013). The internet as an alternative path to internationalization? International Marketing Review, 30(2), 130-155. doi: 10.1108/02651331311314556

Sousa, C. M. P., Martínez-López, F. J., \& Coelho, F. (2008). The determinants of export performance: A review of the research in the literature between 1998 and 2005. International Journal of Management Reviews, 10(4), 343-374. doi: 10.1111/j.14682370.2008.00232.x

Sousa, N., Rueda-Cantouche, J. M., Arto, I., \& Andreoni, V. (2012). Extra-EU exports and employment. European Commission, DG Trade Chief Economist Notes, 2012(2), 1-20.

Stiglitz, J. E. (2018). Globalization and its discontents revisited: Anti-globalization in the era of trump. New York: Penguin Books.

Suarez-Ortega, S. (2003). Export barriers: Insights from small and medium-sized firms. International Small Business Journal, 21(4), 403-419. doi: 10.1177/02662426030214002

Suarez-Ortega, S. M., \& Alamo-Vera, F. R. (2005). Smes' internationalization: Firms and managerial factors. International Journal of Entrepreneurial Behavior \& Research, 11(4), 258-279. doi: 10.1108/13552550510603298

Sun, P., Mellahi, K., \& Thun, E. (2010). The dynamic value of MNE political embeddedness: The case of the Chinese automobile industry. Journal of International Business Studies, 41(7), 1161-1182. doi: 10.1057/jibs.2009.94

Sun, P., Mellahi, K., \& Wright, M. (2012). The contingent value of corporate political ties. Academy of Management Perspectives, 26(3), 68-82. doi: 10.5465/amp.2011.0164

Tesfom, G., \& Lutz, C. (2006). A classification of export marketing problems of small and medium sized manufacturing firms in developing countries. International Journal of Emerging Markets, 1(3), 262-281. doi: 10.1108/17468800610674480

UNCTAD. (2016). World investment report: Investor nationality: Policy challenges. New York.

Uner, M. M., Kocak, A., Cavusgil, E., \& Cavusgil, S. T. (2013). Do barriers to export vary for born globals and across stages of internationalization? An empirical inquiry in the emerging market of Turkey. International Business Review, 22(5), 800-813. doi: 10.1016/j.ibusrev.2012.12.005

Welch, E. D., Welch, S. L., Young, C. L., \& Wilkinson, F. I. (1998). The importance of networks in export promotion: Policy issues. Journal of International Marketing, 6(4), 66-82.

Welfens, P. J. J. (2017). An accidental brexit: New EU and transatlantic economic perspectives. Houndmills, Basingstoke, UK: Palgrave Macmillan.

Westhead, P., Wright, M., \& Ucbasaran, D. (2001). The internationalization of new and small firms: A resource-based view. Journal of Business Venturing, 16(4), 333-358. doi: 10.1016/S0883-9026(99)00063-4

Wiedersheim-Paul, F., Olson, H. C., \& Welch, L. S. (1978). Pre-export activity: The first step in internationalization. Journal of International Business Studies, 9(1), 47-58.

Wilkinson, T., \& Brouthers, L. E. (2006). Trade promotion and SME export performance. International Business Review, 15(3), 233-252. doi: 10.1016/j.ibusrev.2006.03.001

Wold, H. (1980). Model construction and evaluation when theoretical knowledge is scarce. In J. Kmenta \& J. B. Ramsey (Eds.), Evaluation of econometric models (pp. 47-74). New York: Academic Press

WTO. (2016). World trade report 2016: Levelling the trading field for SMEs. 
Yamin, M., \& Kurt, Y. (2018). Revisiting the Uppsala internationalization model: Social network theory and overcoming the liability of outsidership. International Marketing Review, 35(1), 2-17. doi: 10.1108/IMR-11-2014-0345

Zhang, X., Ma, X., Wang, Y., Li, X., \& Huo, D. (2016). What drives the internationalization of Chinese SMEs? The joint effects of international entrepreneurship characteristics, network ties, and firm ownership. International Business Review, 25(2), 522-534. doi: 10.1016/j.ibusrev.2015.09.001

Zhou, L., Wei-ping, W., \& Xueming, L. (2007). Internationalization and the performance of born-global SMEs: The mediating role of social networks. Journal of International Business Studies, 38(4), 673-690. doi: 10.1057/palgrave.jibs. 8400282

Zou, S., \& Stan, S. (1998). The determinants of export performance: A review of the empirical literature between 1987 and 1997. International Marketing Review, 15(5), 333-356. doi: $10.1108 / 02651339810236290$ 


\section{Appendix - Figures and Tables}

Figure 1: Conceptual model

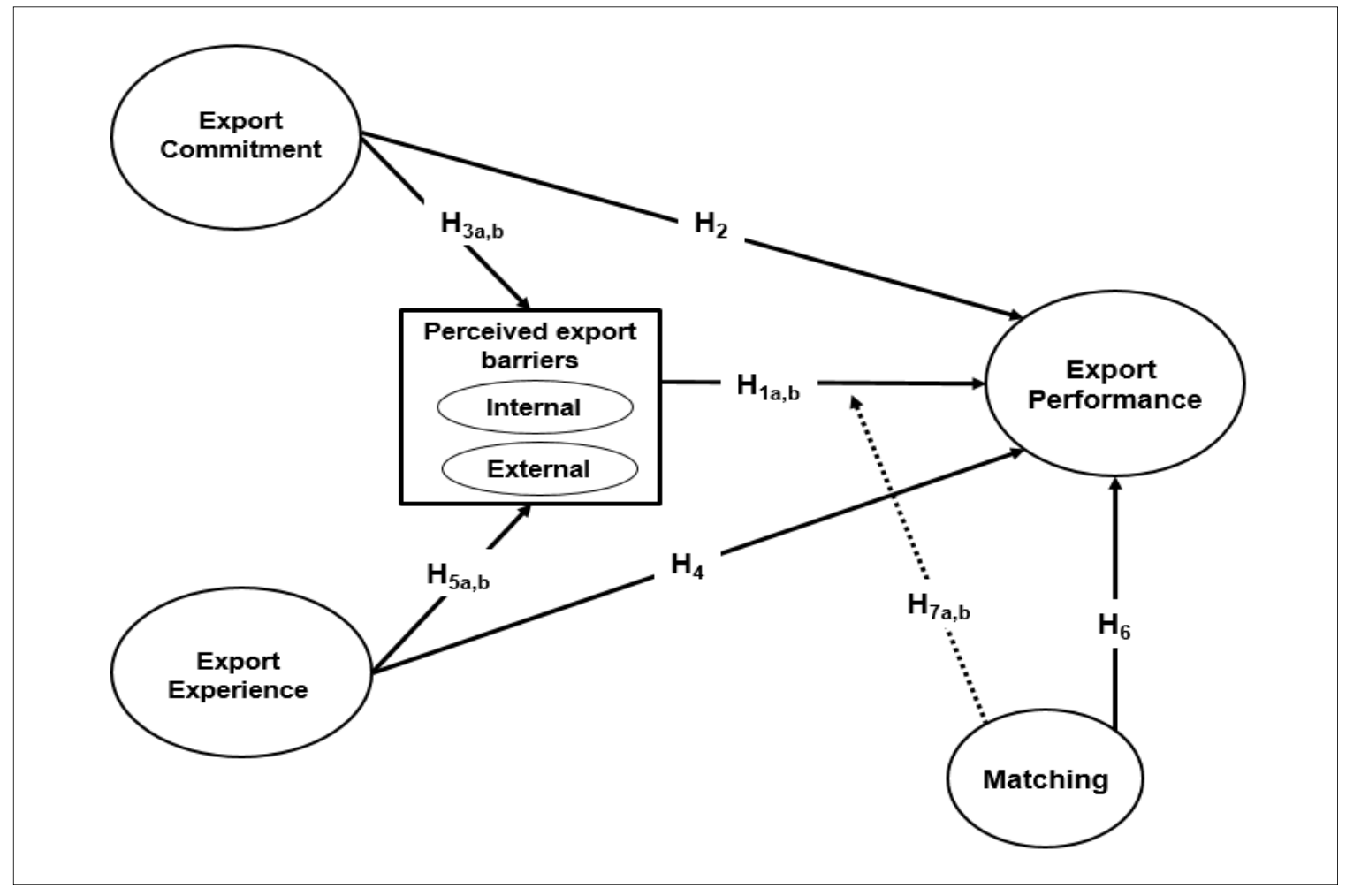


Table 1: Measurement scales

\begin{tabular}{|c|c|c|}
\hline Construct measures & $\begin{array}{l}\text { Outer } \\
\text { loadings }\end{array}$ & t-value \\
\hline \multicolumn{3}{|l|}{$\begin{array}{l}\text { Matching }(\mathrm{CR}=0.782, \mathrm{AVE}=0.644)(\text { strongly disagree }=1, \text { strongly agree }=6, \\
\text { neither agree nor disagree }=0)\end{array}$} \\
\hline \multicolumn{3}{|l|}{$\begin{array}{l}\text { Micro-level networking activities } \\
\mathrm{AVE}=0.701)(\text { (strongly disagree }=1, \text { strongly agree }=7)\end{array}$} \\
\hline $\begin{array}{l}\text { The company commits significant resources to making contact with existing } \\
\text { customers. }\end{array}$ & 0.822 & 10.370 \\
\hline $\begin{array}{l}\text { The company commits significant resources to making contact with new/potential } \\
\text { customers. }\end{array}$ & 0.905 & 10.949 \\
\hline $\begin{array}{l}\text { The company commits significant resources to making contact with existing } \\
\text { suppliers. }\end{array}$ & 0.828 & 8.536 \\
\hline $\begin{array}{l}\text { The company commits significant resources to making contact with new/potential } \\
\text { suppliers. }\end{array}$ & $\mathbf{0 . 7 3 0}$ & 7.656 \\
\hline Overall the company is proactive in taking initiatives to create new contacts. & 0.840 & 4.973 \\
\hline \multicolumn{3}{|l|}{$\begin{array}{l}\text { Macro-level networking activities }(\text { Cronbach's alpha }=0.744, \mathrm{CR}=0.816 \text {, } \\
\mathrm{AVE}=0.543)(\text { strongly disagree }=1, \text { strongly agree }=7)\end{array}$} \\
\hline $\begin{array}{l}\text { There are strong/tight bilateral agreements between our home market government } \\
\text { and the host government of the particular market. }\end{array}$ & 0.670 & 3.278 \\
\hline $\begin{array}{l}\text { The company has established good relationships with local government in this } \\
\text { particular market. }\end{array}$ & 0.818 & 4.504 \\
\hline $\begin{array}{l}\text { The company has established good relationships with local agents/consultants in } \\
\text { this particular market. }\end{array}$ & 0.934 & 4.716 \\
\hline $\begin{array}{l}\text { The company has explored possibilities for local financing (banks/local government } \\
\text { loans etc.). }\end{array}$ & 0.430 & 2.011 \\
\hline \multicolumn{3}{|l|}{$\begin{array}{l}\text { Internal barriers } \\
\text { all }=1, \text { very } \operatorname{much}=7)\end{array}$ Cronbach's alpha $\left.=0.839, \mathrm{CR}=0.879, \mathrm{AVE}=0.510\right)($ not at } \\
\hline Lack of managerial time to deal with exports & 0.685 & 10.313 \\
\hline Inadequate/untrained personnel for exporting & 0.757 & 14.370 \\
\hline Lack of excess production capacity for exports & 0.820 & 19.151 \\
\hline Limited international market data & 0.655 & 8.812 \\
\hline Difficulty in identifying foreign business opportunities & 0.686 & 11.024 \\
\hline Unavailability of warehousing facilities abroad & 0.698 & 11.060 \\
\hline Difficulty in developing new products for foreign markets & 0.688 & 9.439 \\
\hline \multicolumn{3}{|l|}{$\frac{\text { External barriers }}{\text { all }=1, \text { very much }=7)}($ Cronbach's alpha $=0.712, \mathrm{CR}=0.816, \mathrm{AVE}=0.528)($ not at } \\
\hline Unfamiliar exporting procedures/documentation & 0.805 & 10.637 \\
\hline Inability to contact overseas customers & 0.624 & 4.320 \\
\hline Different socio-cultural environments & 0.745 & 7.013 \\
\hline Unfamiliar foreign business practices & 0.722 & 6.582 \\
\hline \multicolumn{3}{|l|}{$\begin{array}{l}\text { Export commitment } \\
\text { (strongly disagree }=1, \text { strongly agree }=7)\end{array}$} \\
\hline We are committing significant resources to the export venture. & 0.937 & 49.662 \\
\hline Management is demonstrating strong commitment to the export venture. & 0.943 & 70.071 \\
\hline \multicolumn{3}{|l|}{$\begin{array}{l}\text { Export performance }(\text { Cronbach's alpha }=0.945, \mathrm{CR}=0.958, \mathrm{AVE}=0.822) \\
\text { (not at all satisfied }=1, \text { very satisfied }=6)\end{array}$} \\
\hline Export sales ratio & 0.883 & 28.435 \\
\hline Export sales growth & 0.944 & 76.698 \\
\hline Export sales volume & 0.957 & 92.551 \\
\hline Contribution of exporting to profits & 0.797 & 12.065 \\
\hline Overall export performance & 0.944 & $\mathbf{7 9 . 8 3 5}$ \\
\hline
\end{tabular}


Table 2: Descriptive statistics of the sample

\begin{tabular}{|c|c|c|c|c|c|c|c|}
\hline Sectors & $\%$ & Firm age & $\%$ & $\begin{array}{l}\text { Size of } \\
\text { firms } \\
\text { (employees) }\end{array}$ & $\%$ & $\begin{array}{l}\text { Export } \\
\text { experience }\end{array}$ & $\%$ \\
\hline Engineering & $31.10 \%$ & 1-5 years & $14.0 \%$ & $\mathbf{1}$ & $3.3 \%$ & Up to 5 years & $32.6 \%$ \\
\hline Textiles & $10.40 \%$ & 6-10 years & $14.0 \%$ & 2 to 5 & $20.9 \%$ & 6 to 10 years & $18.5 \%$ \\
\hline Chemicals & $4.70 \%$ & 11-15 years & $10.8 \%$ & 6 to 10 & $11 \%$ & 11 to 20 years & $20.7 \%$ \\
\hline Automotive & $3.80 \%$ & $16-20$ years & $10.8 \%$ & 11 to 25 & $24.2 \%$ & 21 to 30 years & $9.8 \%$ \\
\hline Furnishing & $2.80 \%$ & 21-25 years & $9.7 \%$ & 26 to 50 & $14.3 \%$ & 31 to 40 years & $8.7 \%$ \\
\hline Giftware & $1.90 \%$ & 26-30 years & $7.5 \%$ & 51 to 100 & $12.1 \%$ & $\begin{array}{l}41 \text { years and } \\
\text { over }\end{array}$ & $9.8 \%$ \\
\hline Biotechnology & $0.90 \%$ & 31-50 years & $14.0 \%$ & 101 to 250 & $14.3 \%$ & & \\
\hline Electronics & $0.90 \%$ & $51-100$ years & $10.8 \%$ & & & & \\
\hline Other & $42.40 \%$ & $\begin{array}{l}\text { more than } \\
100 \text { years }\end{array}$ & $7.5 \%$ & & & & \\
\hline
\end{tabular}

Table 3: Discriminant validity

\begin{tabular}{|l|l|l|l|l|l|l|l|l|l|l|l|l|l|l|l|}
\hline \multicolumn{9}{|c|}{} & \multicolumn{9}{|c|}{ Fornell-Lacker criterion } & \multicolumn{9}{|c|}{} & \multicolumn{3}{|c|}{$\begin{array}{l}\text { Heterotrait-monotrait ratio } \\
\text { (HTMT) }\end{array}$} \\
\hline & EP & EC & EE & EB & IB & MC & & & EP & EC & EE & EB & IB & MC \\
\hline EP & $\mathbf{0 . 9 0 7}$ & & & & & & & EP & & & & & & \\
\hline EC & 0.450 & $\mathbf{0 . 9 4 0}$ & & & & & & EC & 0.497 & & & & & \\
\hline EE & 0.225 & -0.007 & $\mathbf{1 . 0 0 0}$ & & & & & EE & 0.232 & 0.025 & & & & \\
\hline EB & -0.184 & -0.298 & -0.254 & $\mathbf{0 . 7 1 9}$ & & & & EB & 0.204 & 0.359 & 0.290 & & & \\
\hline IB & -0.454 & -0.366 & -0.414 & 0.665 & $\mathbf{0 . 7 1 4}$ & & & IB & 0.507 & 0.425 & 0.456 & 0.855 & & \\
\hline MC & 0.317 & 0.349 & -0.107 & -0.082 & -0.064 & $\mathbf{0 . 8 0 3}$ & MC & 0.473 & 0.569 & 0.165 & 0.227 & 0.180 & \\
\hline
\end{tabular}

Notes: EP: export performance; EC: export commitment; EE: export experience; EB: external barriers; IB: internal barriers; MC: matching. Fornell-Lacker criterion: bold figures on the diagonal are the square roots of AVE. 
Table 4: Assessment of the structural model

\begin{tabular}{|c|c|c|c|}
\hline Hypothesized relationships & $\begin{array}{l}\text { Standardized } \\
\text { coefficient }\end{array}$ & t-statistic & $\begin{array}{l}\text { Statistically } \\
\text { significant? }\end{array}$ \\
\hline $\begin{array}{l}\text { H1a: internal barriers } \rightarrow \text { export performance } \\
\text { H1b: external barriers } \rightarrow \text { export performance }\end{array}$ & $\begin{array}{l}-0.324 * \\
0.140\end{array}$ & $\begin{array}{l}2.378 \\
1.222\end{array}$ & $\begin{array}{l}\text { Yes } \\
\text { No }\end{array}$ \\
\hline H2: export commitment $\rightarrow$ export performance & $0.333 * *$ & 3.449 & Yes \\
\hline $\begin{array}{l}\text { H3a: export commitment } \rightarrow \text { internal barriers } \\
\text { H3b: export commitment } \rightarrow \text { external barriers }\end{array}$ & $\begin{array}{l}-0.369 * * \\
-0.300 * *\end{array}$ & $\begin{array}{l}4.116 \\
2.976\end{array}$ & $\begin{array}{l}\text { Yes } \\
\text { Yes }\end{array}$ \\
\hline H4: export experience $\rightarrow$ export performance & $0.146 *$ & 2.205 & Yes \\
\hline $\begin{array}{l}\text { H5a: export experience } \rightarrow \text { internal barriers } \\
\text { H5b: export experience } \rightarrow \text { external barriers }\end{array}$ & $\begin{array}{l}-0.417 * * \\
-0.256 * *\end{array}$ & $\begin{array}{l}5.752 \\
3.038\end{array}$ & $\begin{array}{l}\text { Yes } \\
\text { Yes }\end{array}$ \\
\hline H6: matching $\rightarrow$ export performance & $0.251 *$ & 2.231 & Yes \\
\hline $\begin{array}{l}\text { H7a: matching } * \text { internal barriers } \rightarrow \text { export } \\
\text { performance }\end{array}$ & $-0.308 *$ & 2.371 & Yes \\
\hline $\begin{array}{l}\text { H7b: matching* external barriers } \rightarrow \text { export } \\
\text { performance }\end{array}$ & 0.209 & 1.705 & No \\
\hline Control variable & & & \\
\hline$\overline{\text { Firm size }}$ & $0.099 *$ & 2.052 & Yes \\
\hline
\end{tabular}


Figure 2: Assessment of the structural model

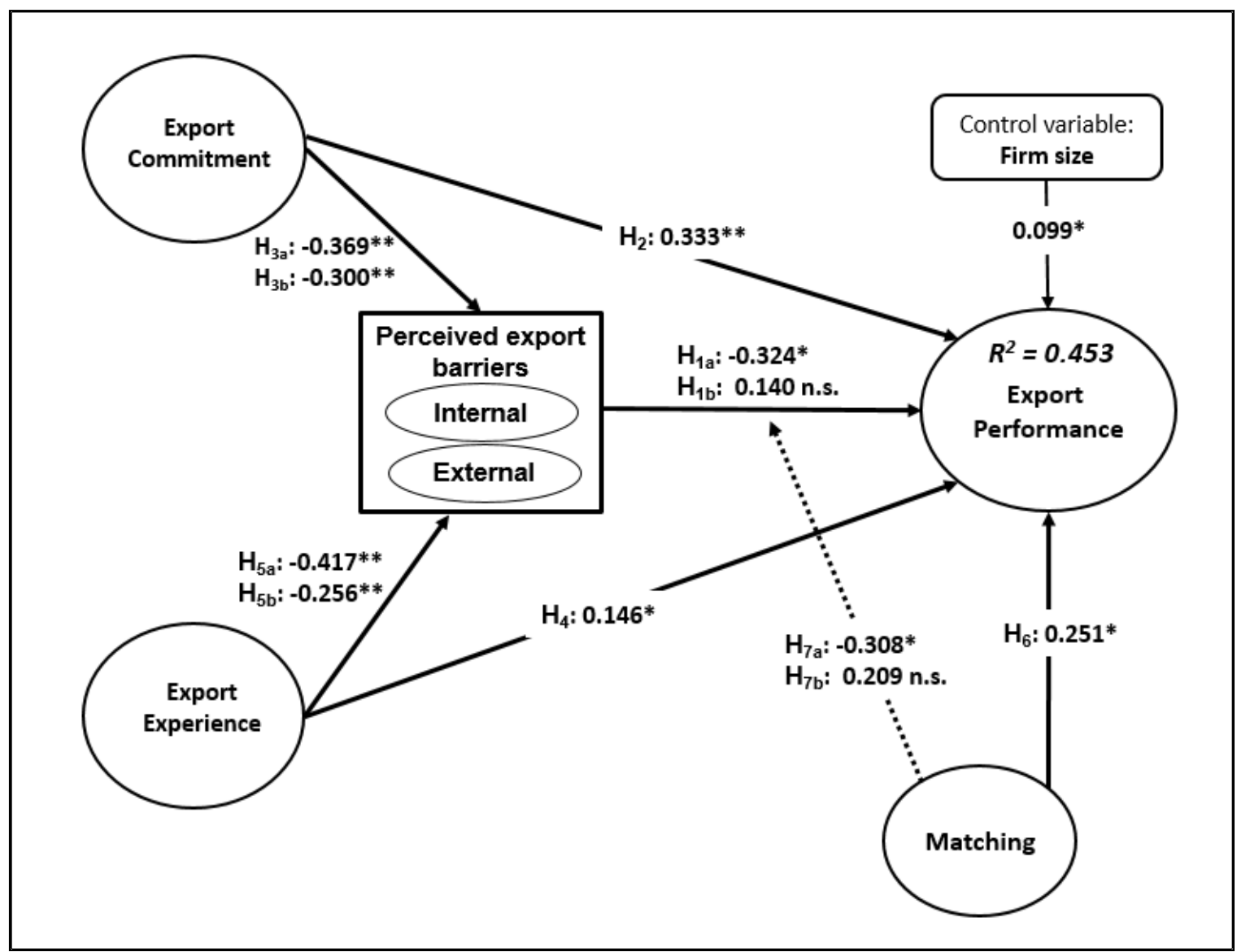

Note: ${ }^{* *}, \mathrm{p}<0.01 ; *, \mathrm{p}<0.05$ 